Araștırma Makalesi - Gönderim Tarihi: 1 Mart 2019 - Kabul Tarihi: 28 Kasım 2019

\title{
Üniversite Yönetimi ve Öğrenci Illetișiminde Sosyal Medya Kullanımı: Fenomen Rektörler ${ }^{1}$
}

\author{
Gaye TOPA CiFTÇi² \\ Murat Ertan DOĞAN ${ }^{3}$
}

Öz

2000'li yıllarda, dijital iletişimin ortaya çıkardığı paradigma değişikliğini fark ederek sosyal medya kullanımının avantajlarını ve önemini kavrayan yükseköğretim yöneticileri sosyal medyayı bir iletişim kanalı olarak kullanmaya başlamışlardır.

Türkiye'de rektörler, genelde, sosyal medya platformlarından iletişim kurmaya en uygun ortamlardan biri olan ve mobil teknolojilerden de erişim sağlanabildiği için, kolaylığına ek olarak yaygın bir şekilde kullanılan Twitter yoluyla iletişimi tercih etmektedir. Rektörlerin iç ve dış paydaşlarla iletişim ve etkileşim kurmak için Twitter'ı kullanmaları, sık sık gerek ulusal gerekse yerel basında kendine yer bularak, bu kanalı tercih eden rektörlerin basında ve toplumda "Fenomen Rektör" olarak anılmasına neden olmuştur.

Bu çalışmanın amacı öğrenci ile sosyal medya kanalıyla iletişim kurarak basında ve toplumda fenomen olarak anılan üniversite yönetiminin en üst kademe yöneticisi olan rektörlerin Twitter paylaşımlarını inceleyerek rektörlerin sosyal medya kullanımı ile ilgili mevcut durumu ortaya koymaktır.

Araştırmanın örneklemi amaçlı örneklem yöntemi ile seçilmiştir. Araştırma nitel olarak desenlenmiş bir durum çalışmasıdır. Veriler doküman incelemesi yöntemi ile toplanarak, betimsel analizin bir çeşidi olan pasif analiz yöntemiyle incelenmiştir. Bulgular alanyazın doğrultusunda oluşturulmuş 5 kategoride yorumlanmıştır.

Araştırmadan elde edilen bulgulara göre, rektörlerin Twitter'ı bir iletişim aracı olarak kullanmalarının tanınırlıklarına etki ettiği, söz konusu rektörlerin takipçi sayılarının artmasıyla birer mikro-şöhret haline getirdiği ve bağlı bulundukları üniversitelerin marka değerini yükseltmede etkili olabileceği sonucuna ulaşılmıştır. Ayrıca istek, sorun ve şikayetlerine cevap alabilen öğrencilerin eğitim motivasyonlarının olumlu yönde etkilendiği ve üniversiteye yönelik kurumsal aidiyet duygularının arttığı gözlemlenmiştir.

Anahtar Kelimeler: Dijital iletişim, Yeni medya, Sosyal Medya, Twitter, mikro-şöhret, influencer

Atıf: Topa Çiftçi, G. ve DOĞAN, M. E. (2019). “Üniversite Yönetimi ve Öğrenci Illetișiminde Sosyal Medya Kullanımı: Fenomen Rektörler”. Akdeniz Üniversitesi Illetișim Fakültesi Dergisi, (AKIL) Aralık (32), s. 269-297

1 Bu çalışma 1-3 Kasım 2018 tarihleri arasında Akdeniz Üniversitesinde düzenlenen 3. Uluslararası Medya Çalışmaları Sempozyumunda sözlü bildiri olarak sunulmuştur.

2 Dr. Öğretim Üyesi, Alanya HEP Üniversitesi, İletişim Tasarımı ve Yönetimi Bölümü.ORCID: 0000-0003-2013-0956 3 Dr. Öğretim Üyesi, Alanya HEP Üniversitesi, İletişim Tasarımı ve Yönetimi Bölümü.ORCID: 0000-0001-6668-5952 


\title{
University Management And Student: Phenomenon Rectors
}

\begin{abstract}
In the 2000s, higher education managers who realized the advantages and importance of social media use by recognizing the paradigm shift of digital communication started to use social media as a communication channel.

In Turkey, the rectors usually prefer to communicate via Twitter, which is widely used thanks to its ease, as it can be used in mobile technologies, which is one of the most appropriate environments to transmit messages among social media platforms. The use of Twitter by the university rectors to communicate and interact with internal and external stakeholders has often found its place in both national and local press, and has led to the fact that the rectors who prefer this channel become a phenomenon.

The purpose of this research is to examine the usage features of Twitter of the rectors who communicate via social media and become a phenomenon. The sample of this research was chosen through purposive sampling method. The model of the research is the case study of qualitative research types. Data were collected through document review method, and were analyzed by using passive analysis which is a derivative of descriptive analysis method.

Findings were examined under the titles of tweet types, the interactivity of communication, the content of the tweets, the language used, the extent to which they responded to the students' wishes and expectations.

According to the findings obtained from the research, it was concluded that the use of Twitter as a communication tool of the rectors influenced their recognition, increasing number of followers led them to be micro-celebrities, however, it raises the brand value of the universities they are affiliated with. In addition, it may affect the motivation of the students who responded to their requests, problems and complaints were affected positively and the sense of corporate belonging towards the university increased.
\end{abstract}

Keywords: Digital Communication, New Media, Social Media, Twitter, micro-celebrity, influencer

\section{Giriș}

Dijital iletişim araçları paylaşımı durmaksızın devam eden bilgi akışını sağlaması ve bilgi edinme olanaklarını sürekli geliştirmesi nedeniyle 21. yüzyılda günlük hayatın vazgeçilmez unsurları haline gelmişlerdir. Özellikle yeni medya araçlarından mobil teknolojilerin kullanım yaygınlığı ve kolaylığı ile birlikte öne çıkan sosyal medyaya devamlı erişilebiliyor olması sayesinde kişiler ve kurumlar arası bilgi ve enformasyon akışı yoğun bir şekilde bu araçlarla gerçekleşmesine olanak sağlamıştır. 2000'li yıllarda dijital iletişim teknolojilerinin getirdiği kolay ve hızlı bilgi alışverişinin sağladığı üstünlükleri farkına varıp önemini kavrayan kişi ve kurumlar gelişimlerini hızlandırarak popüler hale gelmektedir (Cantoni ve Tardini, 2008: s.183). Bir başka deyişle, dijital iletişim araçlarıyla kurumsal iletişimin, yeni medya platformlarından olan sosyal medya üzerinden sağlanması ile genel bilgilendirmeler, kişisel veya kurumsal mesajlar ilk kaynaktan yayılabilmekte ve bu sayede, hedef kitle veya tüzel kişilerle bire bir 
iletişim kurulmasıyla ilgili zamansal, mekansal, hiyerarşik ve bürokratik kısıtlar ortadan kalkabilmektedir. Bu şekilde, kişiler ve kurumlar arası etkileşimli iletişim ortamları oluşturularak, kişilerin doğrudan bilgi edinebilmesi konusunda tatmin sağlanmakta, kurumların da imajları olumlu yönde etkilenmektedir (Lei, vd., 2019: s.34).

Bu çerçeveden bakıldığında üniversitelerde de, üst düzey yönetim ve üniversitenin diğer yöneten ve yönetilenleri arasında birebir iletişimin sağlanabilmesinin önemli avantajları beraberinde getirdiği düşünülmektedir. Geleceğin teminatı olarak görülen üniversite öğrencilerinin gerek eğitim gerekse eğitim aldıkları üniversitelerdeki sosyal yaşamla ilgili alınan kararlarda söz sahibi olmaları ve yorum yapabilmeleri öğrencilerin yaşam kalitesini ve motivasyonlarını arttırmaktadır. Bununla birlikte, üniversitelerde hiyerarşik olarak en üst kademede yer alan rektörler ile öğrencilerin iletişiminde, dijital iletişimin olanakları ortaya çıkmadan önce önemli kısıtlar bulunduğunu söylemek mümkündür.

Bir rektör ile öğrencilerin doğrudan iletişim kurabilmesi, rektörlerin iş yoğunluğu ve hiyerarşik yapıdan dolayı sınırlı şekilde gerçekleşebilmektedir. Dijital iletişim araçlarının gelişmesi ve özellikle sosyal medyanın yoğun kullanımı ile meydana gelen paradigma değişikliğinden sonra yukarıda sözü edilen avantajları göz önüne alan ve önemini kavrayan rektörler, sosyal medya araçlarını gerek öğrencilerle iletişimde gerekse kurumsal iletişim kanalı olarak kullanmaya başlamışlardır.

Bu bağlamda, iletişimin kesintisiz olarak devamını sağlamak için dijital iletişim araçlarını kullanan üniversite yönetimlerinin öğrencilerle iletişiminde sosyal medya kullanımlarının araştırılması tüm üniversitelere ve yönetimlerine örnek olması açısından önem arz etmektedir.

$\mathrm{Bu}$ araştırma için dijital iletişim araçları, dijital iletişim bağlamında sosyal medya, üniversite yönetimlerinin ve öğrencilerinin sosyal medya kullanımları incelenmiştir.

\section{Dijital İletișim Teknolojileri ve Sosyal Medya}

Dijital iletişim ve yeni medya birbirinden ayrılamayacak ve birbirine girişik bir döngüde gelişimlerini sürdüren iki yapıdır. Bunun sebebi yeni medya teknolojilerinin dijital iletişimin araçları, kanalları ve ortamları olmasıdır. Bu noktada alanyazında ortaya çıkan bazı kavramsal karmaşalar dikkat çekmektedir. Yeni medya, iletişim teknolojilerini kullanarak kitle ve bireysel iletişimin gerçekleşmesine olanak sağlayan; toplumların dillerini, kültürlerini, sosyal yapılarını ve bu bağlamda tüm yaşam şartlarını etkileyen tüm kanallar, araçlar ve ortamlar olarak tanımlanabilir (Manovich, 2001: s.117).

Bu noktada da dijital iletişimin sağlandığı yeni medya araçları ve yeni medya ortamları olarak ikiye ayrılması daha anlamlıdır. Bilgisayarlar, akıllı televizyon ve telefonlar, tabletler, Google gözlükler el terminalleri araç takip ekipmanları, telemetriler yeni medya araçları olarak adlandırılırken; bu araçlar ile erişim sağlanabildiği Apple'ın Siri isimli uygulaması ve sanal oyunlar gibi yapay zeka uygulamaları, sosyal medyanın kullanıldığı web uygulamaları yeni medya ortamları olarak adlandırılabilir. Dijital iletişim çerçevesindeki tüm bu yapılar bir birini tamamlayan ve gelişimlerini birbiri ile birlikte devam ettiren kavramlar ve teknolojilerdir. 
Mobil teknolojilerle erişilebilmesi ve ara yüzlerin kullanım kolaylığı nedeniyle dijital iletişim kurmak için yaygın şekilde kullanılan sosyal medya, günlük yaşamda en çok kullanılan yeni medya ortamlarındandır. Bu nedenle dijital iletişim bağlamında sosyal medya kullanımının araştırılması önem teşkil etmektedir.

İnsanların birbirleriyle iletişime geçmesi ve etkileşim içerisinde olmasını anlatan sosyal kelimesi ile, yazılı ve görsel basın gibi kitle iletişim araçlarını kapsayan medya kelimesinin birlikte kullanımı ile oluşan sosyal medya kavramı artık günlük hayatta sıkça kullanılmaktadır. Ayrıca medya kelimesi, kitle iletişim araçlarının yanı sıra haberin yaratılma ve servis edilme sürecinde kullanılan görsel işitsel ögeleri de bünyesinde toplamakta ve bu açıdan da sosyal medya kavramının oluşmasında doğrudan etkisi görülmektedir (Safko ve Brake, 2009: s.3). Aynı dijital iletişim kavramında olduğu gibi, sosyal medya kavramı ile ilgili de farklı tanımlar ve yaklaşımlar görülmektedir. Sosyal medya, kullanıcılarının veri, bilgi, duygu ve düşünce paylaşabildikleri, eş zamanlı ve eş zamansız etkileşim kurabildikleri çevrimiçi araçlar ve web siteleri için kullanılan bir terimdir.

Sosyal medya, dünya çapında kişisel ve kurumsal seviyede sürekli olarak büyüyen bir yapıdır. Sosyal medya alanı içerisinde, Facebook, Twitter, Linkedln, MySpace, Google+, Instgram, Pinterest, YouTube ve bunlara benzer birçok yerel uygulama yer almaktadır. Yukarıda sözü edilen sosyal medya araçlarının her birinin kendine özgü özellikleri bulunmaktadır. Örneğin, YouTube video, Instagram fotoğraf/görsel paylaşımı için kullanılırken, Facebook en yaygın sosyal ağ sitesidir. Bunlara ek olarak, Linkedln genellikler iş ağı üzerinde profesyonel bağlantıların kurulması için kullanılırken, Twitter bireylerin 140 karakterlik bir alanda resimler ve/veya kısa videolar ile düşüncelerini paylaştıkları bir mikro-blog servisidir (Agostino ve Arnaboldi, 2016: s.3).

İçeriği oluşturan kullanıcıların gönüllü olarak metinsel, görsel veya işitsel multimedya içeriklerini paylaşmasına izin veren bir altyapıya sahip olan sosyal medya ortamları, yapısal olarak internet kullanımının teknolojik boyutuna vurgu yapmakla birlikte; içeriğin üretim ve paylaşım aşamalarına kadar uzanan sosyal rolleri de kapsayan bir süreci içermektedir (Doğru ve Doğru, 2015). Sosyal medyada kullanıcılar içerik üreticisi, dağıtıcısı gibi farklı roller üstlenerek sosyal medyayı oluşturan birer unsur haline gelmektedirler. Ayrıca sosyal medya araçları, kişi ya da kurumun direkt olarak hedef kitlesi ile iletişime geçmesine olanak sağlamaktadır (Breakenridge, 2008: s.14).

Sosyal medya, herkesi katkı sağlama ve geri bildirim konusunda cesaretlendirerek medya ve izleyici arasındaki çizgiyi bulanıklaştırdığı için kullanıcılar katılım göstermek mecburiyetinde kalır ve bunu gönüllü olarak yaparlar. Aynı zamanda bu katılım gerçekleşirken ağların büyük bir bölümü katılım ve geri bildirime açık bir durumdadır. Geleneksel medya içeriğin izleyiciye iletildiği veya dağıtıldığı bir yayıncılık biçimi olarak karşımıza çıkarken, sosyal medyada iletişim alıcıyı da sürece dahil ederek iki yönlü bir iletişim biçimi gerçekleştirerek diyalog kurmaya izin verir. Bununla birlikte toplulukların etkili ve hızlı bir biçimde iletişim ve etkileşim kurmasına imkan tanırken, ortak ilgi alanlarını paylaşan fakat gerçek yaşamda bir araya belki de hiç gelemeyecek bireylerin bir araya gelmelerini de sağlamaktadır. 


\section{1.Üniversite Öğrencilerinin Üniversite Üst Yönetimi ile İletișim Aracı Olarak Sosyal Medya Kullanımları}

Sosyal medyanın yarattığı sanal kamusal alan, üniversitelerde birbiri ile etkileşim halinde olan bireylerin büyük bir kısmının gündelik etkileşimlerini sosyal medya ortamına da taşımalarına olanak sağlamaktadır. Üniversitede var olan bireylerin, akademik, idari personel ve öğrenciler olmak üzere, gündelik hayatlarında bir iletişim aracı olarak sosyal medyayı kullanmaları doğal olarak üniversitede oluşan kamusal alan üzerinde de iletişimlerini sıklıkla sosyal medya üzerinden sürdürmelerine de olanak tanımaktadır.

Bu çerçevede, üniversiteler kurumsal iletişimlerini yeni ve etkili bir mecra olan sosyal medya üzerinde de yönetirlerken öğrenciler, akademisyenler ve diğer paydaşları da üniversiteleri sosyal medyada takip etmektedirler. Bu doğrultuda, sosyal medyanın kişileri ve kurumları etiketlemeye olanak tanıması, mobil iletişim araçları ile sürekli aktif paylaşım ve etkileşim imkanı sağlaması da söz konusu kullanımın sürekli oranda artmasını beraberinde getirmektedir(Roebuck, vd., 2013: s.187).

Yolcu (2013: s.369) yaptığı araştırmada, üniversitelerin Twitter'ı sadece tanıtım amaçı ı değil, takipçilerine bilgi vermek ve sorulan soruları yanıtlamak amacıyla da kullanıldıkları sonucuna varmıştır. Bu çerçevede, üniversitelerin ve üniversitelerin üst yöneticilerinin paylaşımları ve takipçileri ile olan iletişimleri informal bir dil kullanılarak gerçekleşmektedir. Böylelikle, üniversite ve yöneticileri ile öğrencilerin iletişim ve etkileşiminde bürokratik yapıdan kaynaklanan birçok sınılıılık aşılabilmektedir.

Twitter'ın yaygın kullanım alanı, kısa ve öz iletişim yöntemi ve takip edilme bilme özelliği yükseköğretim kurumlarının bu sosyal medya platformuna olan ilgisini artırmıştır. Lieratürdeki araştırmalar Twitter mesajlarının çoğunlukla monolojik ve pazarlamaya yönelik bir yapıya sahip olduğunu söylemektedir. Bununla birlikte, Twitter'ın dialojik ve karşılıklı konuşmaya da izin veren yapısı ideal bir halkla ilişkiler aracı olarak da kullanımasına imkan tanımaktadır (Kimmons, vd., 2016: s. 100). Bu durum birçok yükseköğretim kurumunun kurumsal olarak bir Twitter hesabı sahibi olmalarına neden olmaktadır.

Twitter aramalar yapılabilen bir etiketleme (hashtag) özelliğine de sahiptir. Kullanıcılar başkalarının tweetlerini retweet ederek tekrar paylaşabilmekle birlikte, paylaşımların başına "@” işareti konularak diğer kullanıcıların kendilerine yönelik mesajlarını da paylaşılabilmektedir. Böylelikle, bir konu ve kişiler paylaşımlarda etiketlenerek algı ve ilgi konuya ve konuyla ilişkili kişilere yönlendirilebilmektedir (Palmer, 2013: s. 334-335). Öğrenciler, yükseköğretim kurumları ve kurum yöneticileri herhangi bir olay üzerinde birbirlerini etiketleyerek paylaşım yapabilme, soru sorabilme ve eleştiri ve şikayette bulunabilme şansını doğrudan muhataplarını hedef alarak yakalamaktadırlar. Bunun yanı sıra, kişiler arasında başkalarının göremeyeceği doğrudan mesajlaşmaya yönelik bir serviste mevcuttur. Etiketleme sistemi olayların kişi ve kurumlarla ilişkilendirilerek kamusal alana taşınması için benzersiz bir fırsat sunmaktadır.

2018 yılı itibariyle Türkiye'de bulunan 54,3 Milyon internet kullanıcısının 51,45 milyonu aktif olarak mobil internet kullanmaktadır. Söz konusu mobil internet kullanıcısı 
sayısı toplam ülkenin toplam nüfusunun \%63'üne denk gelmektedir. Bu çerçevede, Türkiye'de internet kullanıcıları öncelikli olarak Google, YouTube, Facebook ve Twitter isimli web sitelerini kullanmaktadır. Twitter internet sitesi 2018 yılında aylık 188 milyon ziyaretçi almıştır, Facebook ise ayda 785 milyonun üzerinde ziyaret edilmiştir (Hootsuite, 2018).

Bu doğrultuda, sosyal medya üzerinde yüksek sayıda takipçisi bulunan ve bir nevi kanaat önderi haline gelen kişilerin paylaşımları ağ üzerinde sürekli yeniden paylaşıldığında kişiler popülerleşerek Türkçede "internet fenomeni" olarak adlandırılmaktadırlar. Sosyal medyayı aktif kullanan üniversite rektörleri de öğrencilerin yanı sıra üniversitenin iç ve dış paydaşları ile söz konusu mecralardan kurdukları iletişim ve etkileşim doğrultusunda birer fenomen haline gelebilmektedirler.

Türkçede "internet fenomeni" veya "sosyal medya fenomeni" olarak tabir edilen bireylerle ilgili literatürdeki çalışmalar farklı kavramlar üzerinden tartışılmaktadır. Bu kavramların büyük bir kısmı kişisel markalama veya kişisel markalaşma olarak Türkçede kullanılan "personal branding" veya "self-branding" kavramları üzerinden tartışılabilir

Kişisel Markalama (personal branding veya self branding) bireylerin kültürel sermaye ve/veya ticari getiri sağlamak amacıyla toplumda kendine özgü bir imaj yaratmaları olarak tanımlanabilir. Burada önemli bir nokta ise hedeflenen kitlenin ilgi ve ihtiyaçlarına yönelik duyarlı, yanıt veren ve karizmatik bir toplumsal kimlik oluşturulması düşüncesidir (Khamis, vd., 2017).

Sosyal medya üzerinden kişisel markalama yaratılmış bir öyküleme ve ilgi üzerine yönelmektedir, böylelikle önemli ölçüde şöhret potansiyelini artırmaktadır. İlgi uyandıran bir hikayenin ortaya çıkıyor olması çok farklı nedenlerle izleyici/takipçilerin ilgisini de cezbedebilmektedir. Örneğin bu nedenler paylaşımların, ilham verici, kişilerin kendilerinde bir şeyler bulduğu (relatable), öğretici/yol gösterici, ikaz edici nitelikte olmasından kaynaklanabilir. Böylelikle, farklı sosyal medya uygulamaları arasında paylaşılan bu tür öyküler takipçilerin/izleyicilerin/hayranların kendi kişisel hesaplarındaki beğeni, paylaşım ve yorumları ile daha geniş bir alana yayılma imkanı bulmaktadır (Page, 2012: s.184). Bu durum, sosyal medya ve konvansiyonel medyanın tüm araçlarında var olan karşılıklı etkileşimler ile hikâye veya paylaşımı başlatan kişilerin kişisel markalaşmasını da sağlayarak bireylerin takipçi sayısı vb. etkenlerden bağımsız olarak öncelikle şöhretlenmesini daha sonra ise takipçi sayısının artarak bir fenomen haline gelebilmelerini sağlayabilmektedir.

Yukarıda da söz edildiği üzere sosyal medya, farklı hikayeleri olan veya kendine özgü içerikleri paylaşan sıradan kullanıcıları içinde barındırmakta ve söz konusu bazı kullanıcıların yüksek görünürlüğe ve popülariteye ulaşmasını sağlayacak bir yapıya sahiptir. Bu yüksek görünürlük rakamları ayrılamaz bir şekilde kişisel markalamaya bağlanmaktadır. Sosyal medyada takip edilmeye başlamak bir hayran kitlesine sahip olmayı ve sıradan bir kişinin büyük bir üne sahip olmasına neden olabilmektedir. İngilizce literatürde micro-celebrity kelimesi ile karşımıza çıkan bireylerin ün kazanarak orta çaplı şöhret olması durumu genellikle Türkiye'de "sosyal medya fenomeni", "internet fenomeni" olmak olarak tabir edilmektedir. Mikro-şöhret olarak Türkçeye çevrile- 
bilecek olan Micro-celebrity kavramını ilk kez 2001 yılında Theresa M. Senfit video, bloglar ve sosyal ağ sitelerinde popülerleiklerini artırmaya çalışan ve kamerakızı (camgirl) olarak adlandırılan bireyler üzerine yaptığı araştırmasında kullanmıştır (Senfit, 2008: s. 25).

Burada önemli bir saptama da Türkiye'de Sosyal Medya Fenomeni olarak adlandırılan bazı mikro-şöhretlerin sahip olduğu sosyal medya kanallarında bir ürünü, hizmeti, markayı veya bunlar üzerindeki kişisel deneyimlerini paylaşmasıdır. Literatürde "social media influencer" olarak adlandırılan bireyler kişisel markalaşmalarını sosyal ağlar üzerinde reklam, tüketiciye ulaşma amacıyla şirketlerle anlaşma yaparak kullanabilmektedirler (Hern ve Schoenhoff, 2016: s.194-195). Kısaca "Influencer" olarak adlandırılan bu kişilerin başarıları da çoğunlukla ulaştıkları takipçi sayısı, maddi gelirleri, sahip oldukları menkul ve gayrimenkul kıymetler üzerinden değerlendirilmektedir.

Social Media Influencer olarak adlandırılan kişiler markaların ve organizasyonların sosyal medya içindeki varlığı açısından da önem taşımaktadır. Türkçede de sosyal medya fenomeni olarak bilinen ve milyonlarca takipçisi bulunan bu kişilerin yanı sıra, takipçi sayısı binlerle veya on binlerle ifade edilen micro-influencer olarak bilinen fenomenler de bulunmaktadır. Bu tip sosyal medya fenomenlerinin bir kısmı milyonlarca takipçisi olanlardan daha çok güvenirlik faktörüne sahip olabilirler (Barhorst, vd., 2019). Günlük yaşam içerisinde herhangi bir olayla veya hizmetle ilgili olumlu ve olumsuz bildirimlerini maddi kaygı olmadan paylaşan bu tipteki fenomenler zaman zaman markaların ve şirketlerin imajları üzerinde daha fazla takipçisi bulunan sosyal medya fenomenlerine göre daha büyük etki sahibi olabilmektedir.

Üniversitelerin en üst yöneticisi olan rektörlerin öğrencilerle iletişim ve etkileşim kurduğu Twitter ortamında farklı paydaşların da internet üzerindeki kamusal alanda ilgili paylaşımlara ulaşması, paylaşılan iletilerin büyük kitlelere ulaşması ve geri bildirimler alması rektörleri birer "Sosyal Medya Fenomeni" haline getirmektedir. Bu araştırmada "Sosyal Medya Fenomeni” olarak algılanan üniversite rektörlerinin Twitter kullanım özellikleri sosyal ağ teorisi çerçevesinde incelenmektedir.

Bu çalışmada Twitter üzerinde paylaşım yapan ve orta ölçekte şöhret sahibi olan üniversite rektörleri influencer kavramı çerçevesinde tartışılmamaktadır. Çalışma kapsamında mikro-şöhret olarak adlandırılabilecek olan rektörler kamu yararına çalışmaktadır. Bu doğrultuda, yapılan saptamalar ve değerlendirmeler söz konusu rektörleri birer fenomen olarak tanımlamakta kullanımakla birlikte, hali hazırda kamuya ait üniversitelerin görünürlüğünü ve marka değerini de artıran rektörlerin kişisel bir getiri (maddi, siyasi, kültürel sermaye vb. ) amacıyla paylaşım yapmadıkları varsayılmaktadır.

\section{Kuramsal Çerçeve}

\subsection{Sosyal Ağ Teorisi}

Sosyal ağ ile ilgili çalışmalar ilk olarak Emile Durkheim ve Ferdinand Tonnies tarafından yapmış oldukları çalışmalar ile yüz yıl kadar önce ortaya konmaya çalışılmıştır. İlk sonuçlar 1908 yılında Georg Simmel tarafından alınmış ve 1930'lu yıllara gelindiğinde artık sosyal ağ teorisi; sosyoloji, psikoloji ve felsefe gibi temel bilim dallarının bir parçası 
haline gelmiştir.

Sosyal ağ teorisi, grup dinamikleri ve sosyometrinin oluşması çalışmalarına dayanmaktadır (Moreno, 1934: s.175). İnsan ilişkilerinde kişilerarası uygulamalara dönük sosyometri, özellikle insanların seçim yaparken farklı görev ve farklı durumlarda nasıl birbirinden farklı davrandığını ölçer (Blumberg ve Hare, 1999: s.87). Ayrıca sosyometri alanı sürekliliği sağlanabilen gözlemler ve ölçümlemeler için araştırmalara ve araştırmacılara farklı bir alan açarak, grup dinamiklerinde gözlemleme yaklaşımını geliştirmiştir. Bu araştırmalar için olumlu ilerlemelere neden olmuşsa da gruplar arasında değişen dinamiklerin irdelenmemesi bir sınırlılık olarak ortaya çıkmıştır. Bu bağlamda sosyal ağ teorisi disiplinlerarası teorik bir çerçevede, ağların kullanıcıları arasındaki ilişkilerini ifade eden bir teori olarak tanımlanabilir. Bunun yanında Bu teoride ağ yapısının kişisel kullanıcılardan daha önemli olduğu öne sürülmektedir (Scott, 1991: s.11). Teori insanlar, gruplar, bilgisayarlar, telefonlar, URL'ler (bağlantılar), organizasyonlar ve bütün bunların arasındaki ilişkileri, akışları ortaya koyar ve bu ilişkileri ölçer, analiz eder. Bu bağlamda bu teori için sosyal ağ analizi kavramı da kullanılır. Sosyal Ağ Analizinin temel amacı, sosyal ağın her bir kullanıcıyı ne şekilde ve nasıl etkilediğini ortaya koymaktır (Kenan ve Shiri, 2009: s.439). Sosyal ağ teorisi, ilişkilerdeki yapıları ve çıkarımları, özel davranış ilkeleri çerçevesinde açıklayarak ifade etmektedir (Jones, 2009: s.594). Bu noktada da o ağın yapısı analiz etmek çok önemli olacağı açıktır. . Sosyal ağ teorisine göre, sosyal ağ çalışmaları, sosyoloji, antropoloji, psikoloji ve örgütsel çalışmaları içeren aynı zamanda çoğu alanda yararlı bulunan teknikleri geliştirmiş (Finin, vd., 2005: s.420) ve bu tekniklerin takibini kolaylaştırmıştır. Ayrıca bu teori, ağlar üzerindeki ilişki mimarisini ve davranış kalıplarını ifade etmektedir. Sosyal Ağ Teorisinin sahip olduğu varsayımlar; bireyler arasındaki sosyal ilişkilerin, bireyler arası bilgi köprülerinin ve bilginin yayılmasını sağlamaktır. Sosyal Ağ Teorisindeki baş aktörler ise; kişiler, gruplar ve organizasyonlardır. Sosyal Ağ Teorisinin bağımlılıkları ise; diğerleri ile iletişimde olmak ve birliktelik kurmaya olan mecburiyettir. Sahip olduğu mekanizmalar; iletişim mekanizması ve karşılıklı deneyim alışverişidir. Özetle teori bilgi alışverişinde, kişisel kanallar ve/veya medya etkilerinde ve davranışsal değişikliklerde ve/veya hareket kabiliyetindeki sosyal ilişkilerin rolüne odaklanır.

\section{2.Önceki Çalıșmalar}

Barnes ve Lescault (2013) Twitter'ın yükseköğretim kurumları tarafından kullanımı ile ilgili geçmiş araştırmalar çoğunlukla aday öğrencilerin üniversiteye olan ilgisini artırmada kullanıldığını söylemektedir. Bununla birlikte, farklı araştırmalar Twitter'ın üniversitelerin kamuda kendi imajlarını pozitif yönde artırmak üzere kullanıldığını da ortaya koymuştur (Kimmons vd., 2016). Barnes ve Lescault (2013) tarafından gerçekleştirilen üniversite yöneticilerinin Twitter kullanımlarının gözlemlendiği en kapsamlı araştırmada, Amerika Birleşik Devletlerinde 50 eyalette var olan tüm üniversitelerin en üst yöneticilerinin \%55'inin Twitter hesabı olduğu ve bu durumun kendilerini öğrenciler tarafından ulaşılabilir hale getirdiğini söylemektedir. Bununla birlikte aynı çalışmada üniversite üst yöneticilerinin Twitter'da aktif rol almalarının kendi kurumlarının öğrenciler ve öğrenci adayları tarafından nasıl algılandığını izlemekte de kullanıldığının altı çizilmiştir. 
Türkiye'de ise Yolcu (2013) tarafından yapılan bir araştırmada, 10 devlet ve vakıf üniversitenin Twitter kullanımları incelenmiş, Vakıf üniversitelerinde tweetlerin karşılık bulma oranının \%31,15, devlet üniversitelerinde ise bu oranın \%5,78 gibi bir değer aldığı sonucuna ulaşılmıştır. Söz konusu araştırmada genel olarak üniversitelerin Twitter'ı marka değerini artırmak ve üniversitenin promosyonunu yapmak üzere kullanıldığı ifade edilmiştir.

Bununla birlikte, Türkçe literatürde Üniversite rektörlerinin Twitter'daki paylaşımlarını içeriklerinin herhangi bir yöntemle analizinin yapıldığı bir çalışmaya rastlanmamıştır. Bu anlamda, yapılan bu çalışma literatürde bir ilki gerçekleştirdiği için önem taşımaktadır.

\section{Yöntem}

\subsection{Amac}

Bu bağlamda çalışmanın amacı, öğrenci ile sosyal medya kanalıyla iletişim kurarak basında ve toplumda fenomen olarak anılan üniversite yönetiminin en üst kademe yöneticisi olan rektörlerin Twitter paylaşımlarını inceleyerek rektörlerin sosyal medya kullanımı ile ilgili mevcut durumu ortaya koymaktır.

Bu amacı ortaya çıkarabilmek için aşağıdaki araştırma soruları araştırılacaktır.

1.Fenomen rektörlerin attığı tweet türleri nelerdir?

2.Fenomen rektörler Twitter üzerinden kurdukları iletişimde interaktifliği sağlanmış mıdır?

3.Fenomen rektörlerin tweet etkileşimleri nasıldır?

4.Fenomen rektörlerin kurdukları iletişimde tweet içerikleri ve dil kullanımı nasıldır?

\subsection{Araștırmanın Modeli}

Araştırmanın modeli nitel araştırma türlerinden durum çalışması olarak desenlenmiştir. Veriler doküman incelemesi yöntemi ile toplanmıştır. Doküman incelemesi internete dayalı şekilde yapıldığı için bu açıdan internete dayalı araştırmalar için geliştirilmiş ikincil araştırma (Hewson, vd., 2015) tekniği kullanılmıştır. İkincil araştırma internete dayalı yapılan nitel araştırmalarda, önceden birikmiş ve genellikle kamuya açık ve kullanıma/analize hazır verilere dayalı internet araştırmalarına verilen isimdir (Yıldırım ve Şimşek, 2011: s. 225).

Elde edilen veriler internet kaynaklı veri türleri için kullanılan pasif analiz (Eysenbach ve Till, 2001) yöntemiyle incelenerek yorumlanmıştır. Pasif analiz betimsel analizin bir çeşidi olmakla beraber internet üzerinde var olan çeşitli veri türlerinin belirli bir amaçla analiz edilmesidir (Yıldırım, Şimşek, 2011: s.226). Ayrıca internete dayalı araştırmaların genel sınırılığı olan geçerlilik ve güvenirliğin artııııması için birden fazla tekniğinin birlikte kullanımasını ifade eden yöntem içi veya eşzamanlı iç içe geçmiş çeşitleme (Kimchi, vd., 1991: s.364) yönteminden yararlanılmıştır. 
Bu bağlamda verilerin toplanması 3 aşamada gerçekleştirilmiştir. Illk olarak paylaşımlar 5 kategoriye ayrılmıştır.

Bir sonraki aşamada örneklem grubun yaptığı paylaşımlar belirlenen kategorilere göre sınıflandırılarak paylaşımlar hakkında sayısal verilere ulaşılmıştır. Son aşamada ise paylaşımların içerikleri kategorilerin özelliklerine göre incelenerek nitel veriler elde edilmiştir.

Toplanan verilerin analizi için, bulgular arasında neden-sonuç ilişkisi kurularak, gerekli yerlerde olgular arasında karşılaştırmalar yapılmış, gerekli yerlerde de doğrudan alıntılarla desteklenerek veriler yorumlanmıştır.

Özetle çalışma, iki farklı teknikle verileri toplanarak çeşitlemenin gerçekleştirilmesi ile geçerlilik ve güvenirliği güçlendirilmiş, betimsel analiz ile analizleri yapılarak yorumlanmış bir durum çalışması olarak tasarlanmıştır.

\subsection{Katılımcılar}

$\mathrm{Bu}$ araştırmanın katılımcıları amaçlı örneklem yöntemi ile seçilmiştir. Bu çerçevede fenomen olma olgusu takipçi sayısı ile ilişkilendirilmesine karşın geçmiş dönem takipçi sayılarına ulaşılamamasından ve sosyal medya takipçi sayılarının güvenirlik sınırlılığından dolayı basında sosyal medya kullanımı ile en çok öne çıkan, basında ve toplumda fenomen olarak anılan rektörler bu araştırmanın katılımcılarını oluşturmaktadır. Bu çerçevede 2017 yılı Aralık ayı sonunda yapılan araştırmaya göre rektör oldukları dönemde yaptıkları Twitter paylaşımları (tablo 2) ile basında en çok haberi çıkan (tablo 3) 3 rektörün Twitter hesapları incelenmiştir.

Tablo 2: Katılımcıları Oluşturan Rektörler (Katılımcıların tweet sayıları rektörlük görev sürelerinden bağımsız olarak Twitter platformundan atılan tüm tweetleri kapsamaktadır.)

\begin{tabular}{|l|c|c|c|}
\hline $\begin{array}{l}\text { Rektör - Üniversite } \\
\text { (İsimler alfabetik olarak } \\
\text { Sıralanmıştır.) }\end{array}$ & $\begin{array}{c}\text { Rektörlüğe } \\
\text { Atanma Tarihi }\end{array}$ & $\begin{array}{c}\text { Twıtter Hesabı } \\
\text { Açılışı }\end{array}$ & Tweet Sayısı \\
\hline $\begin{array}{l}\text { Prof. Dr. Muhsin KAR } \\
\text { Niğde Ömer Halis Demir } \\
\text { Universitesi }\end{array}$ & 29 Ağustos 2017 & Aralık 2010 & $17.2 \mathrm{~b}$ \\
\hline $\begin{array}{l}\text { Prof. Dr. Mustafa ÜNAL } \\
\text { Akdeniz Üniversitesi }\end{array}$ & 2 Ağustos 2016 & Ocak 2016 & 6.578 \\
\hline $\begin{array}{l}\text { Prof. Dr. Muzaffer ELMAS } \\
\text { Sakarya Üniversitesi }\end{array}$ & 28 Kasım 2010 & Mayıs 2012 & 6.312 \\
\hline
\end{tabular}


Tablo 3: Illetişim Aracı Olarak Sosyal Medya Kullanan Rektörlere Illişkin Yapılan Haber Sayıları (Interpress, Aralık 2017)

\begin{tabular}{|l|c|c|}
\hline Rektör - Üniversite & Ulusal Basın & Yerel Basın \\
\hline $\begin{array}{l}\text { Prof. Dr. Muhsin KAR } \\
\text { Niğde Ömer Halis Demir } \\
\text { Universitesi } \\
\text { (29 Ağustos 2017-31 Aralık 2017) }\end{array}$ & 18 & 118 \\
\hline $\begin{array}{l}\text { Prof. Dr. Mustafa ÜNAL } \\
\text { Akdeniz Üniversitesi } \\
\text { (2 Ağustos 2016- 31 Aralık 2017) }\end{array}$ & 86 & 2.774 \\
\hline $\begin{array}{l}\text { Prof. Dr. Muzaffer ELMAS Sakarya } \\
\text { Universitesi } \\
\text { (28 Kasım 2010-31Aralık 2017) }\end{array}$ & 589 & 9.420 \\
\hline
\end{tabular}

\subsection{Sinırlılıklar:}

$\mathrm{Bu}$ çalışma, katılımcı olarak seçilen rektörlerin 1 Ocak - 31 Ocak 2018 tarihleri arasındaki Twitter paylaşımları ile sınırlıdır. Ayrıca katılımcı rektörlerin varsa yapmış olduğu özel paylaşımlar çalışma kapsamına alınmamıştır. Araştırma katılımcı eğitim, üniversite, öğrenci ve sosyal içerikli paylaşımlarıyla sınırlandırılmıştır. Bunun yanında bu araştırmada sosyal bilimlerde gerçekleştirilen nitel araştırmaların genel sınırlılıkları geçerlidir.

\subsection{Bulgular}

Yapılan araştırma da katılımcı bulunan rektörlerin 1 ay süresince yaptığı paylaşımlar (tweetler) kuramsal temel çerçevesinde oluşturulan, tweet türü, tweet içeriği konusu, tweet etkileşimi, kişi etkileşimi ve kullanılan dil şeklinde 5 ana kategoride incelenmiştir. Kategoriler bağlamında yapılan araştırma ile sayısal verileri elde edilmiştir. Sonrasında tweetlerin içerikleri betimsel analizle incelenerek incelenerek, sayısal verilerle içerikler sentezlenmiş ve yorumlanmıştır.

Tweetlerin türleri rektörlerin kendilerine sorulan sorulara cevap olması, başkalarının tweetlerinin paylaşılması yoluyla retweet yapılması, yapılan alıntılar ve kendilerinin yazdığı orijinal tweetler olarak 4 alt kategoride incelenmiştir. Bu kategoride retweet yapılan paylaşımlara ek yorum yazılması halinde paylaşım hem retweet hem de orijinal veri olarak kaydedilmiştir.

İçerik konusu, tweetlerin içerikleri genel olarak incelendiğinde en çok öne çıkan tanıtım, duyuru, soru cevap, sosyal paylaşım ve diğer alt kategorilerine ayrılarak değerlendirilmiştir. Bazı paylaşımların içerikleri birden çok kategoriye uyum sağlayabildiği için yine bu kategorideki veriler de sayısal çeşitlilik göstermektedir. Örneğin sosyal paylaşım olarak yayınlanan bir tweet aynı zamanda üniversite etiketiyle yayınlandığında bir tanıım tweeti olarak da değerlendirilmiştir.

Tweet etkileşimi olarak adlandırılan, bir tweetin cevaplanması, beğenilmesi ve retweet 
edilme oranları da Twitter üzerinden yapılan paylaşımlar için dijital iletişimi sürdürmesi ve geliştirmesi adına önemli olmasından dolayı incelenerek sayısallaştırılmıştır. Ayrıca rektörlerin paylaşımlarının tek taraflı ve çift taraflı etkileşimi gerçekleştirmesi açısından incelenmesi ile iletişim etkileşimi açısından incelenmiştir. Tüm bu paylaşımların yazım dili formal ve informal olarak 2 alt kategoride değerlendirilmiştir.

\subsubsection{Niğde Ömer Halis Demir Üniversitesi Rektörünün Twitter Kullanımına Yönelik Bulgular}

Niğde Ömer Halis Demir Üniversitesi Rektörü Prof. Dr. Muhsin KAR, paylaşımlarını 2010 yılında açtığı kişisel kullanıcı hesabından yapmaktadır. Bunun yanı sıra rektörlüğe atanmasının ardından Twitter'da özel paylaşımlara yer vermediği, platformu öğrencilerle iletişim kurmak ve bağı bulunduğu üniversiteyi tanıtmak üzerine sadece rektör kimliği ile yaptığı görülmektedir.

Tablo 4: Niğde Ömer Halis Demir Üniversitesi Rektörünün Twitter Kullanımına Yönelik Bulgular

\begin{tabular}{|l|l|l|l|l|l|}
\hline Tweet Türleri & Orijinal & Retweet & Alıntı & Cevap & \\
\hline & 95 & 18 & 6 & 101 & \\
\hline $\begin{array}{l}\text { Tweet } \\
\text { İçerikleri }\end{array}$ & Tanıtım & Duyuru & Soru Cevap & $\begin{array}{l}\text { Sosyal } \\
\text { Paylaşım }\end{array}$ & Diğer \\
\hline & 25 & 38 & 87 & 88 & 10 \\
\hline $\begin{array}{l}\text { Tweet } \\
\text { Etkileşimi }\end{array}$ & Cevaplanma & Beğeni & $\begin{array}{l}\text { Retweet } \\
\text { edilmesi }\end{array}$ & & \\
\hline & 114 & 202 & 150 & & \\
\hline $\begin{array}{l}\text { Tweet } \\
\text { İnteraktifliği }\end{array}$ & Tek Yönlü & Çift Yönlü & & & \\
\hline & 64 & 139 & & & \\
\hline Kullanılan Dil & Formal & İformal & & & \\
\hline & 79 & 124 & & & \\
\hline
\end{tabular}

Araştırmanın yapıldığı Ocak ayı içinde Prof. Dr. Muhsin KAR 203 paylaşımda bulunmuştur.

Muhsin KAR'ın Twitter paylaşımları türleri açısından incelendiğinde alıntı yaptığı ve retweet paylaşımlarının sorulara cevap verdiği ve kendi orijinal paylaşımlarına göre daha az bir oranda olduğu görülmektedir.

Alıntı yaptığı paylaşımların tümünü şiir, hikaye ve şarkı gibi sanat eserleri oluşturmaktadır (resim 1). 


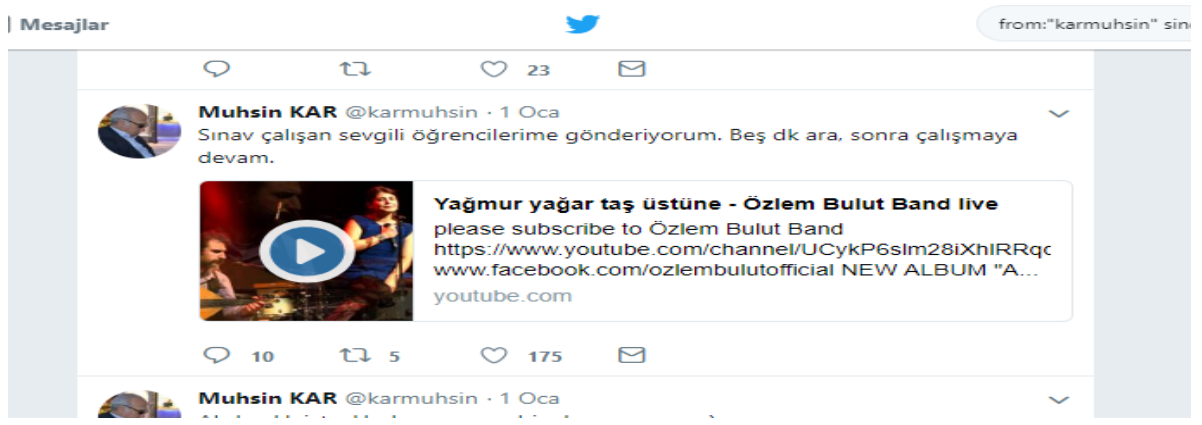

Resim 1: Alıntı Türünde Twitter Paylaşımı

Retweet olan paylaşımlarda ise gerek geleneksel medya gerekse sosyal medyadan dikkat çekici haberleri paylaştığı, bazılarına ise kendisinin de yorum yaptığı görülmektedir (resim 2).

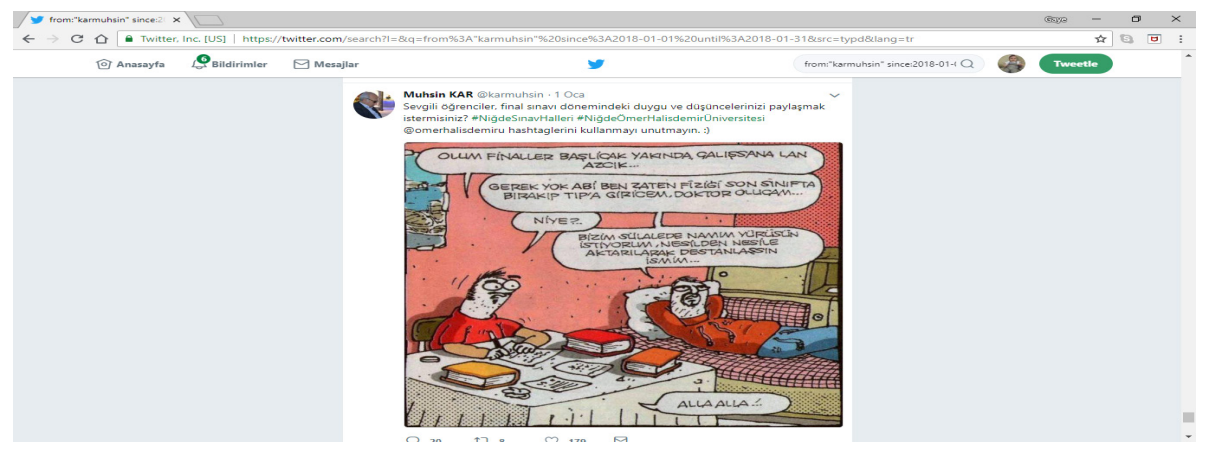

Resim 2: Retweet Türünde Twitter Paylaşımı

Orijinal paylaşımlarında, içinde bulunulan döneme göre sürekli olarak "NiğdeSınavHalleri", "NiğdeÖmerHalisDemirÜniversitesi", "NiğdeOkuyor" gibi farklı etiketlerle öğrencilerin paylaşımlarını belirli gruplar içinde toplamayı başarmıştır (resim 3). Bu şekilde hem öğrencilerinin üniversiteye ilişkin aidiyetlerini gelişmesini desteklemekte, hem de bağlı olduğu üniversitenin adının dijital ortamda sık kullanılanlar arasına girmesine katkıda bulunmaktadır. "Üniversite etiketini kullanmaya özen gösteriyoruz." İçerikli tweeti bunun bir göstergesidir. Bu etiketleri orijinal paylaşımlarında olduğu kadar retweet, alıntı ve cevap paylaşımlarında da kullanmıştır. Bunun yanında sınav dönemlerinde öğrencilerin motivasyonunu arttırmaya yönelik sosyal içerikli paylaşımları yoğunluk göstermektedir. Bu paylaşımlarda aynı zamanda öğrencilerin içinde bulunduğu duruma yönelik mizah unsurlarını sıklıkla kullanmaktadır (resim 3). 


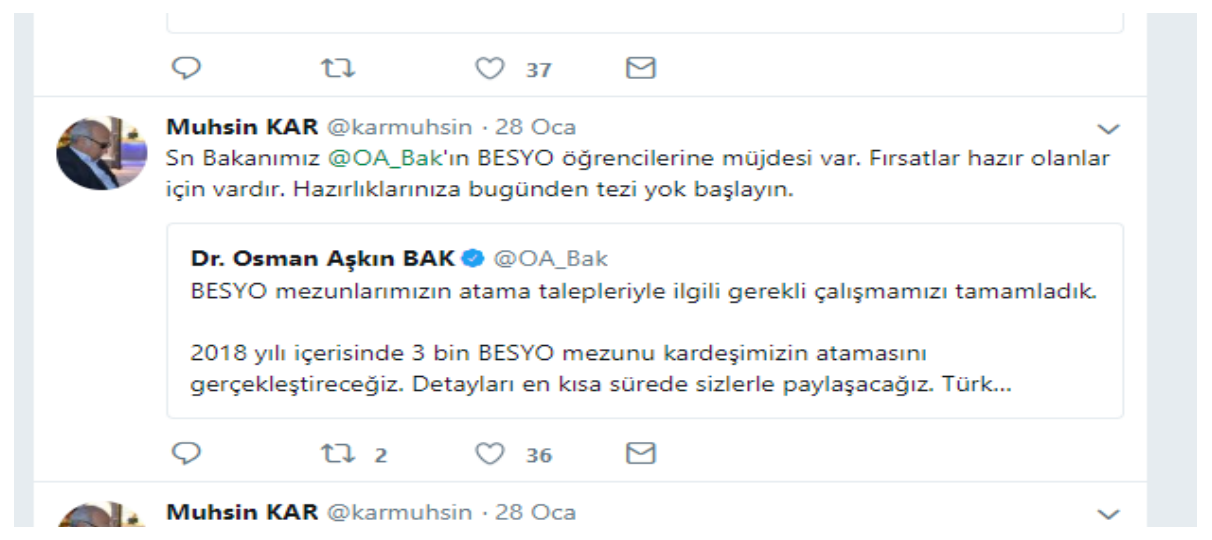

Resim 3: Etiketli Twitter Paylaşımı

Paylaşım içeriklerinde ise soru cevap ve sosyal içerikler ön plana çıkmaktadır. Soru cevap paylaşımlarının içerikleri (resim 4), çoğunlukla öğrencilerin üniversiteye ilişkin soru ve sorunlarını cevaplayarak çözüm bulmak üzerine yoğunlaşmıştır.

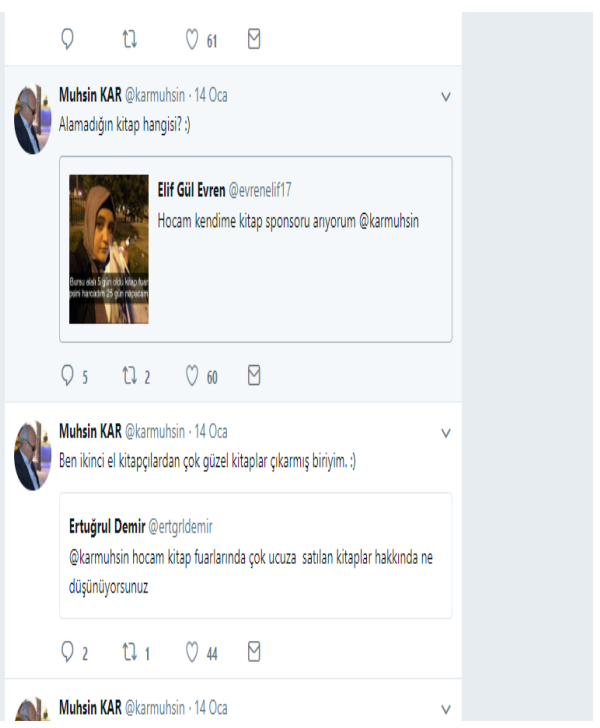

Resim 4: Öğrenci İhtiyaçlarına Cevap Verilen Twitter Paylaşımı

Muhsin Kar'ın toplumdaki ve dünyadaki önemli gelişmelere olan hassasiyeti ve bu konuda sosyal içerikli paylaşımları en az soru cevap içerikli paylaşımları kadar dikkat çekmektedir. Yeni bir buluş veya toplumu ilgilendiren önemli politik gelişmelerle ilgili paylaşımları önemli ölçüde etkileşim almıştır (resim 5). 


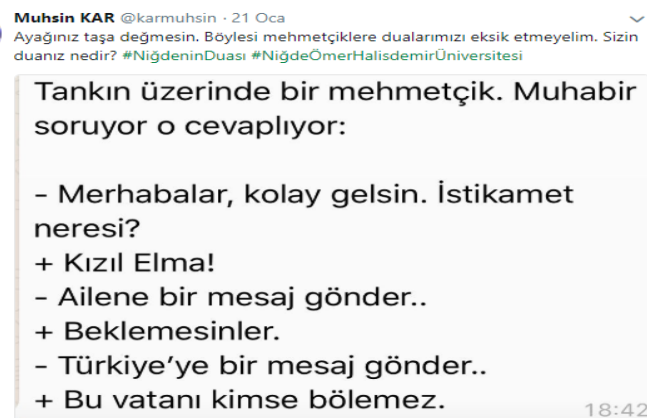

Resim 5: Yüksek beğeni alan Twitter Paylaşımı

Ayrıca bu paylaşımlarında yaptığı yorumlarda öğrencilere soru yöneltmesinin, ilişkili konu ile ilgili öğrencilerde farkındalık yaratma ve tweet için etkileşimin artmasına neden olmaktadır. Bu paylaşımlarında da üniversite ismini içeren etiketlemeler yaptığı görülmektedir.

Bunun yanında sınav dönemlerinde gecenin geç saatlerine kadar ders çalışan öğrenciler için kütüphanede çorba dağıtılması ve buna ilişkin yorumlar gerek Ömer Halis Demir Üniversitesi öğrencileri gerek başka üniversitelerde okuyan öğrenciler ve rektörler tarafından etkileşim almıştır (resim 6).

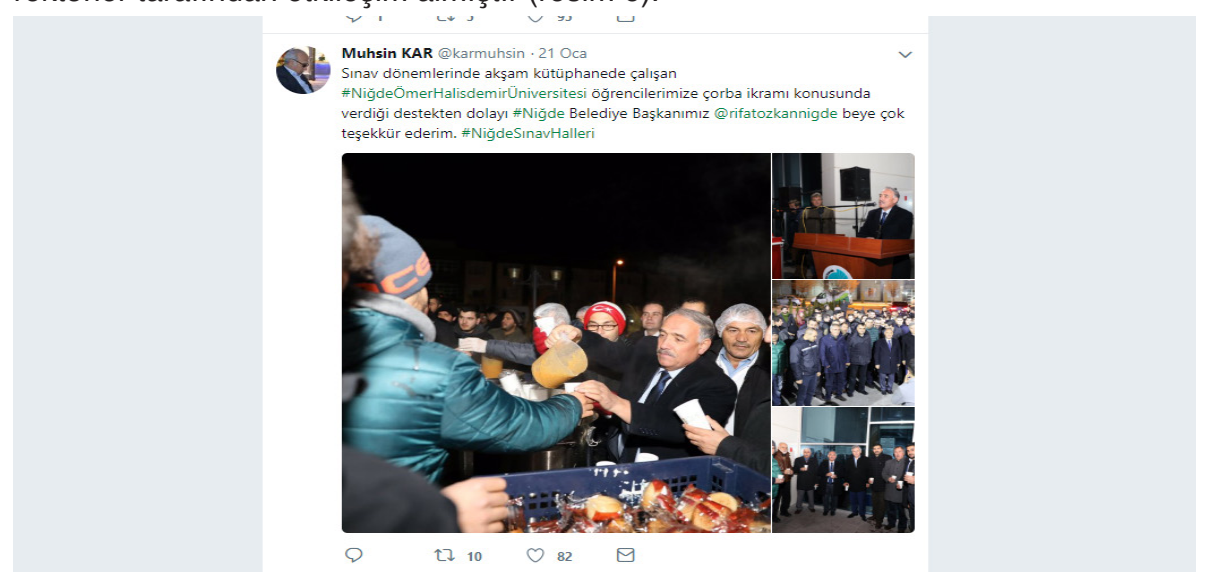

Resim 6: Öğrenciler İçin Yapılan Çalışmalarla İlgili Twitter Paylaşımı

Üniversitenin yarıyıl tatiline girdiği ocak ayı içinde yapılan araştırmada derslerin olmadığı dönemde rektörün Twitter aracılığı ile tanıtım çalışmalarına ağırlık verdiği görülmektedir. Üniversite paydaşlık çalışmaları kapsamında yaptığı gezileri ve üniversitede meydana gelen önemli gelişmeleri üniversite ismi etiketiyle paylaşarak hem duyuru hem de tanıı içerikli paylaşımlar yapılmıştır (resim 7). 


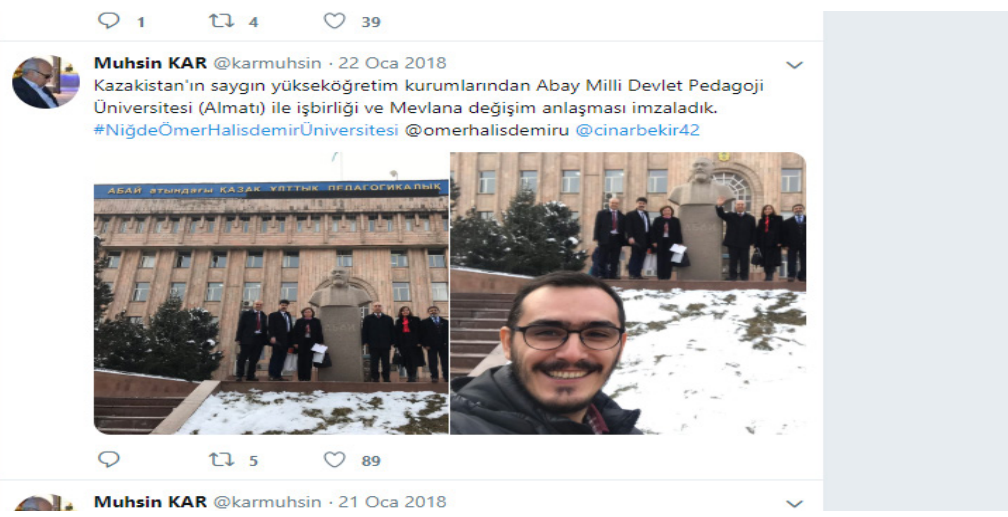

Resim 7: Üniversite Çalışmaları ile İlgili Twitter Paylaşımı

Paylaşımlar etkileşim açısından incelendiğinde, incelemenin yapıldığı süreçte rektörün tüm paylaşımlarının cevaplanma, beğeni, veya retweet edilerek etkileşim aldığı görülmektedir. Araştırmanın yapıldığı dönemde en fazla beğeni alan paylaşımı 569 beğeni ile Türk ordusu ile ilgili paylaşımı olduğu görülmektedir (resim 8).

Muhsin KAR@karmuhsin.19 Oca 2018

Ya Rabbi sen ordumuzu muzaffer eyle. Askerlerimize güç ve cesaret ver.

Yöneticilerimize sağlam irade ver. Vatanımıza göz dikenlerin yüreklerine korku ver. Amin.

Q 7 七】 $56 \quad \bigcirc 569$

Resim 8: En Fazla Beğeni Alan Twitter Paylaşımı

Özellikle Eğitim öğretim dönemi dışında olmasına karşın tanıtım ve duyuru içerikli paylaşımların yüksek etkileşim oranına sahip olması, dijital iletişim kapsamında yapılan bu çalışmaların amacına ulaştığını göstermektedir.

Paylaşımların yarısından fazlasında çift yönlü etkileşimli iletişime geçilmesi ile interaktif bir ortamın oluşturulabildiği sonucuna ulaşılmıştır. İletişimin tek yönlü olduğu paylaşımların duyuru ve tanıtım içerikli paylaşımlar olduğu tespit edilmiştir.

Rektörün paylaşımlarının çoğunda öğrencilerle informal bir dil kullanarak iletişim kurduğu tespit edilmiştir. Formal dili kullandığı paylaşımların tanıtım ve duyuru içerikli paylaşımlar olduğu saptanmıştır.

\subsubsection{Akdeniz Üniversitesi Rektörünün Twitter Kullanımına Yönelik Bulgular}

Akdeniz Üniversitesi Rektörü Prof. Dr. Mustafa Ünal'ın, vekil rektör olduğu tarih itibariyle bir üniversite yöneticisi kimliği ile yeni bir twitter hesabı açması, yükseköğretim kurumunda dijital iletişimi kullanacağının planlanı olarak gösterilebilir. @profmustafaunal kullanıcı ismiyle açılan hesabında öğrenciler başta olmak üzere, üniversite çalışanları, farklı üniversitelerin öğrencileri ve rektörlerinin yanı sıra üniversite öğrenci adayları gibi birçok farklı kesimle sadece üniversite yöneticisi kimliği ile iletişim kurmakta ve hiç özel paylaşımda bulunmamaktadır. 
Tablo 5: Akdeniz Üniversitesi Rektörünün Twitter Kullanımına Yönelik Bulgular

\begin{tabular}{|c|c|c|c|c|c|}
\hline Tweet Türleri & Orijinal & Retweet & Alıntı & Soru cevap & \\
\hline & 43 & 11 & 2 & 87 & \\
\hline \multirow[t]{2}{*}{$\begin{array}{c}\text { Tweet } \\
\text { İçerikleri }\end{array}$} & Tanıtım & Duyuru & Soru Cevap & Sosyal Paylaşım & Diğer \\
\hline & 6 & 34 & 79 & 30 & 11 \\
\hline \multirow[t]{2}{*}{$\begin{array}{c}\text { Tweet } \\
\text { Etkileşimi }\end{array}$} & Cevaplanma & Beğeni & $\begin{array}{l}\text { Retweet } \\
\text { edilmesi }\end{array}$ & & \\
\hline & 77 & 100 & 47 & & \\
\hline \multirow[t]{2}{*}{$\begin{array}{c}\text { Tweet } \\
\text { İnteraktifliği }\end{array}$} & Tek Yönlü & Çift Yönlü & & & \\
\hline & 2 & 102 & & & \\
\hline \multirow[t]{2}{*}{ Kullanılan Dil } & Formal & İnformal & & & \\
\hline & 96 & 8 & & & \\
\hline
\end{tabular}

Araştırmanın yapıldığı Ocak ayı içinde Prof. Dr. Mustafa ÜNAL 104 paylaşımda bulunmuştur.

Mustafa ÜNAL'ın Twitter paylaşımları türleri açısından incelendiğinde alıntı yaptığı ve retweet paylaşımlarının azlığı; orijinal paylaşımlarının da genelde öğrenci sorularına cevap vermek ve sorunlarına çözüm bulmak için kullanması, sosyal medyayı öğrencilerle iletişime geçmek ve öğrenci sorunları ile ilgili kurumlar arası bağ kurmak için alternatif bir kanal olarak kullandığının göstergesidir (Resim 9).

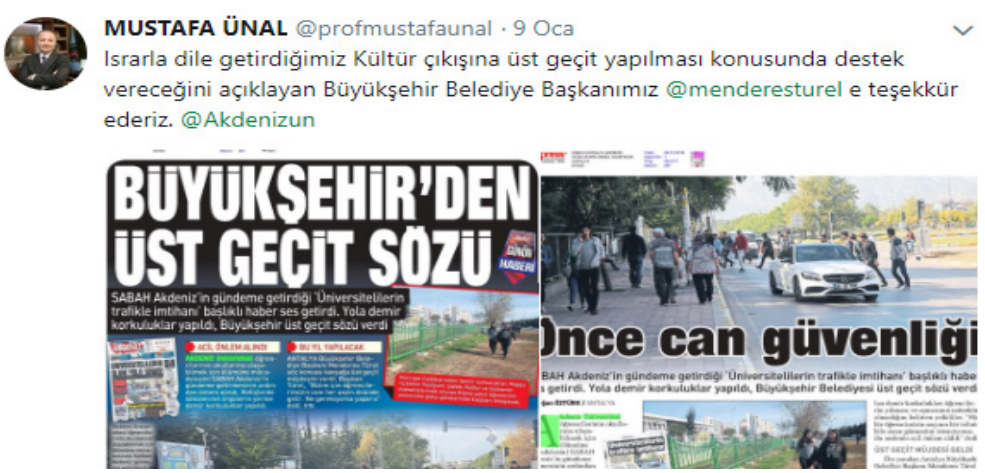

Resim 9: Orijinal tweet örneği

Aynı zamanda orijinal paylaşımlarında kampüs içinde öğrencileri sürekli gözlemlediğine ilişkin yorumlarını mizahi bir söylemle paylaşmıştır (resim 10).

MUSTAFA ÜNAL@profmustafaunal.27 Oca

Aynı anda okey oynayan bu kadar çok kişiyi ilk defa gördüm. Keşke derslerde de bu kadar istekli olsanız. Çarşamba gelin. twitter.com/samisavasss/st...

Bu Tweet kullanım dışıdır.

Resim 10: Mizahi Söylemle hazırlanmış paylaşım örneği 
Soru cevap ve orijinal paylaşımlarına göre daha az bir oranda olsa da özellikle alıntı yaptığı paylaşımların da dünya ve ülke gündemindeki önemli gelişmeleri aktarmıştır (resim 11).

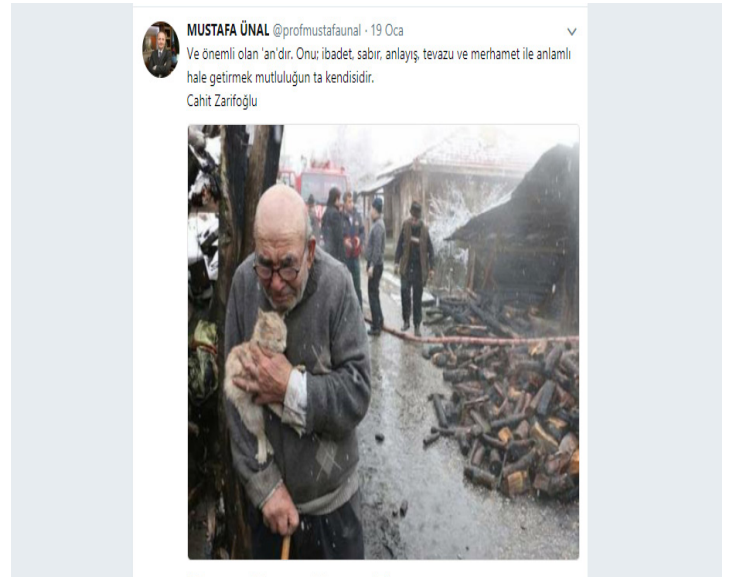

Resim 11: Alıntı Türündeki Twitter Paylaşımı

Retweet paylaşımları genelde üniversite tanıtımına katkıda bulunacak farklı kurumların üniversitenin başarılarını gösteren haberleri içermektedir (resim 12).

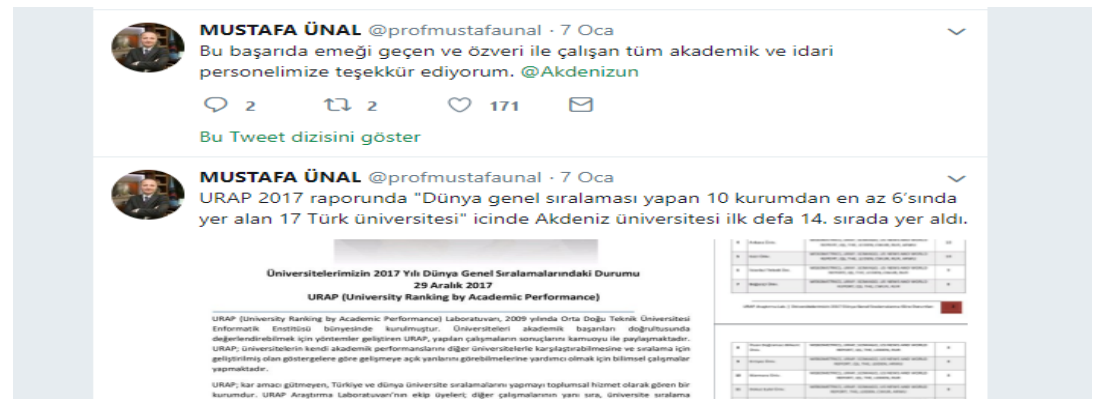

Resim 12: Retweet türündeki Paylaşımı Örneği

Paylaşım içeriklerinde ise öğrencilerle yaptığı soru cevap tarzındaki iletişim ön plana çıkmaktadır. Soru cevap paylaşımlarının içerikleri çoğunlukla öğrencilerin üniversiteye ilişkin soru ve sorunlarını cevaplayarak çözüm bulmak üzerine yoğunlaşmıştır. Öğrencilerin gerek okul ile gerekse yaşamla ilgili tüm sorularını detaylı şekilde inceleyerek ayrıntılı olarak cevaplamıştır (resim 13,14). 


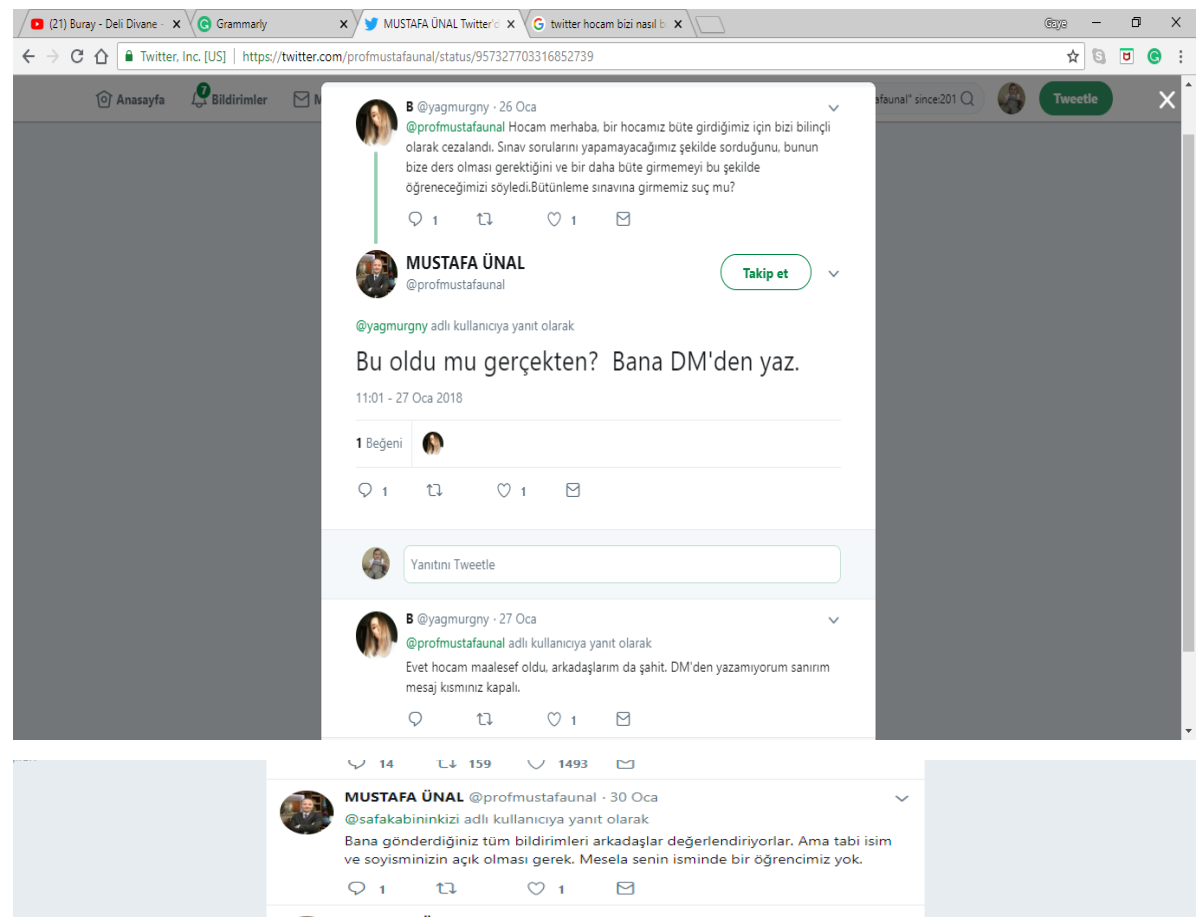

Resim 13: Öğrenci Sorunları ile ilgilendiği Twitter Paylaşımı

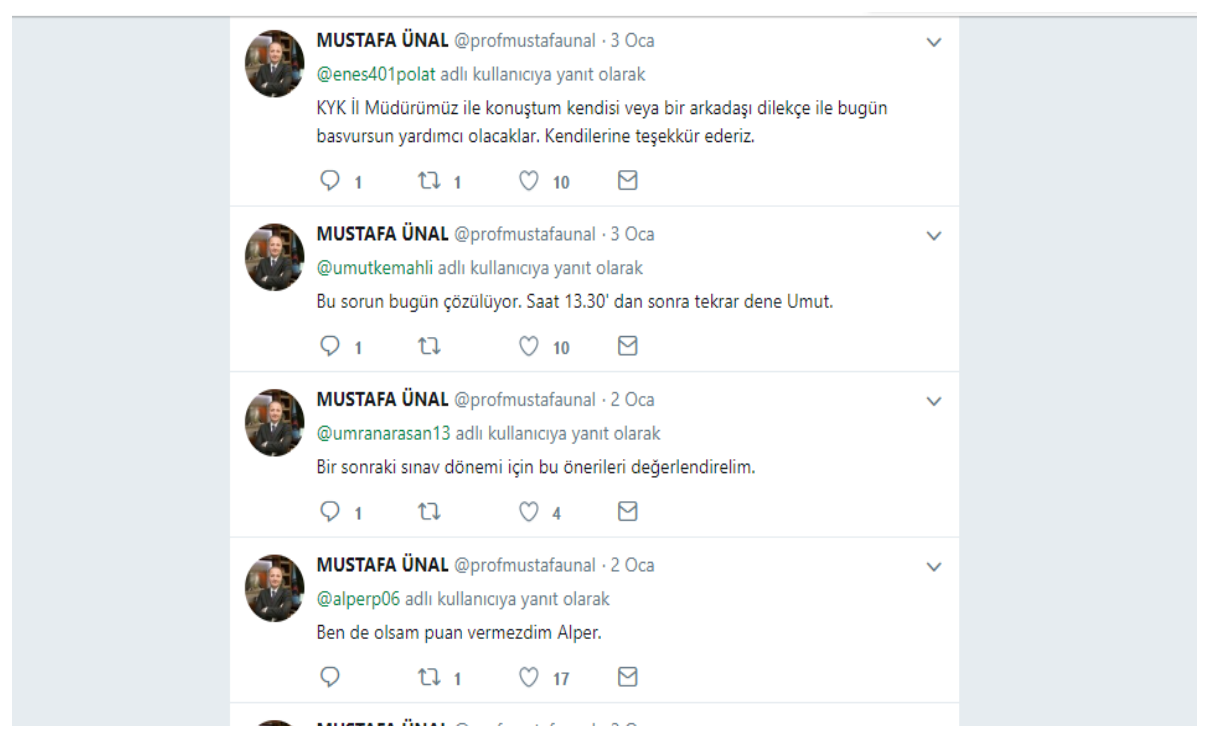

Resim 14: Öğrenci Sorunlarını Çözmeye Yönelik Aracılık Yaptığı Twitter Paylaşımı 
Özellikle toplumsal açıdan önemli politik olaylarla ilgili etiketlemelerle yaptığı içeriğe sahip sosyal paylaşımları da yüksek etkileşim almıştır (resim 15).

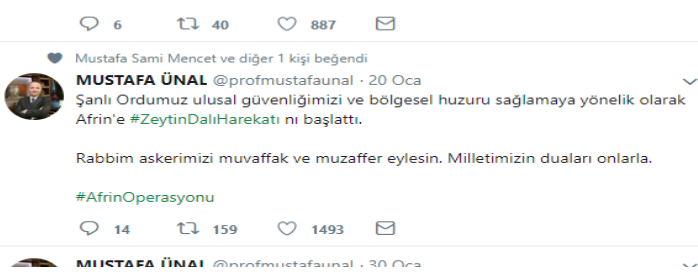

Resim 15: Etiketlemeleli Twitter Paylaşımı

Paylaşımlar etkileşim açısından incelendiğinde, incelemenin yapıldığı süreçte rektörün tüm paylaşımlarının etkileşim aldığı görülmektedir. En fazla beğeni alan paylaşımı 2167 beğeni ile bütünleme sınavı ile ilgili mizahi bir söylemle yaptığı bir paylaşımı tespit edilmiştir (resim 16).

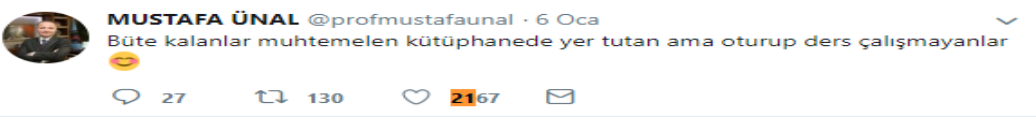

Resim 16: En Çok Etkileşim Alan Twitter Paylaşımı

Bunun yanında öğrencilerinden birinin okuduğu üniversitenin rektöründen telefon faturasını ödemesini isteyebilmesi, rektörün öğrencilerle kurduğu Twitter diyaloglarında etkileşimi en üst seviyeye taşıdığının bir başka örneği olarak tespit edilmiştir (resim 17).

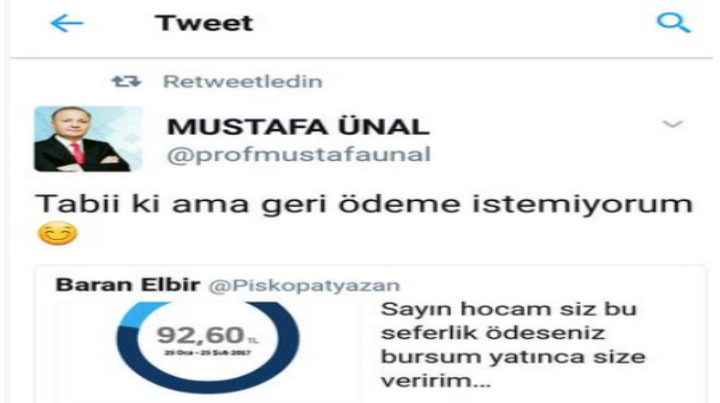

Resim 17: Ulusal Basında Yer Bulan ve Öğrencilerin Özel Sorunlarına Değinilen Twitter Paylaşımı

Bu etkileşim ulusal basında da yer bulmuş, rektör sadece öğrenciler değil tüm Twitter kullanıcıları ile etkileşim kurmaya başlamıştır (resim 18). 


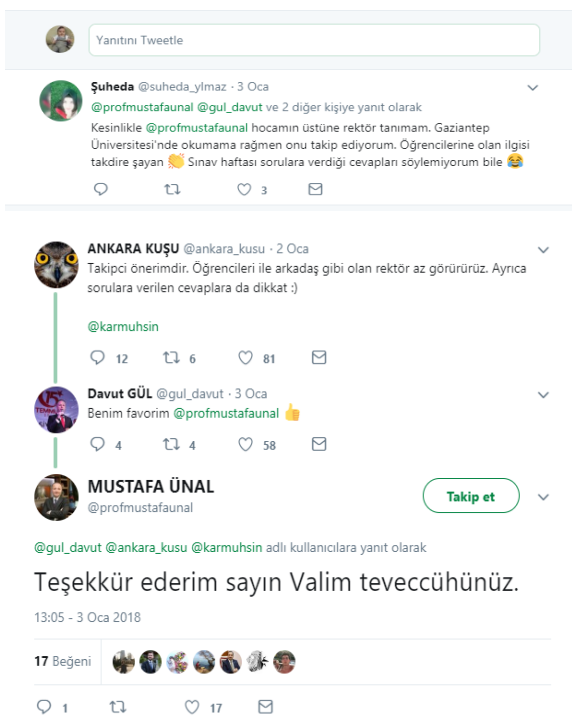

Resim 18: Farklı Kurumlar ve Üniversite Dışı Kişilerle Rektör Kimliği ile Yapılan Twitter Paylaşımları

Paylaşımların 2 tanesi haricinde tüm paylaşımlarda çift yönlü etkileşim sağlandığı görülmektedir. Etkileşimin tek yönlü olduğu paylaşımların duyuru ve tanıtım içerikli paylaşımlar olduğu saptanmıştır. Bu bulgulara dayanarak dijital iletişimde interaktifliği sağlandığı tespit edilmiştir.

Rektörün paylaşımlarının tamamına yakınında öğrencilerle formal bir dil kullandığı tespit edilmiştir (resim 19).

7. MUSTAFA ÜNAL @profmustafaunal ·23 Oca

@onuroztas1 adlı kullanıcıya yanıt olarak

Düzeltildi. Seninkinde hâlâ sorun varsa ögrenci işlerine başvur Onur.

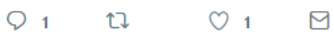

MUSTAFA ÜNAL @profmustafaunal·23 Oca

Alperen üniversitemizin Koruma ve Güvenlik Şube Müdürlügune başvur, buluntu

eşya / para formu var onu doldurarak teslim et. Kaybeden kişi muhtemelen oraya

başvurmuştur.

Alperen Hatunoğlu @kurthanalperen

@profmustafaunal Merhaba hocam, İïB sınırları içerisinde yerde para

buldum. Bir kağıda telefon numaramı yazıp binaların girişine asmama rağmen

irtibat kuran olmadı. Ben de belki sizin aracılığınızla parayı kaybedene

ulaşabilirim diye düşündüm, retweetlerseniz sevinirim.

Bu Tweet dizisini göster

$Q_{2}^{2}$ 七 $\quad O_{16} \quad \square$

MUSTAFA ÜNAL @profmustafaunal.19 Oca

@erkanmcu adlı kullanıcıya yanıt olarak

Kardeşinin karnesi mi bu? Senden daha çalışkanmış tebrikler.

$\begin{array}{lllll}Q_{1} & \uparrow & O & 9 & \square\end{array}$

Resim 19: Paylaşımlardaki Dil Kullanım Örnekleri 
Ayrıca kendisinin etiketlendiği veya üniversiteyi ilgilendiren tüm paylaşımlara itina ile formal bir söylem kullanarak cevap vermektedir (resim 20).
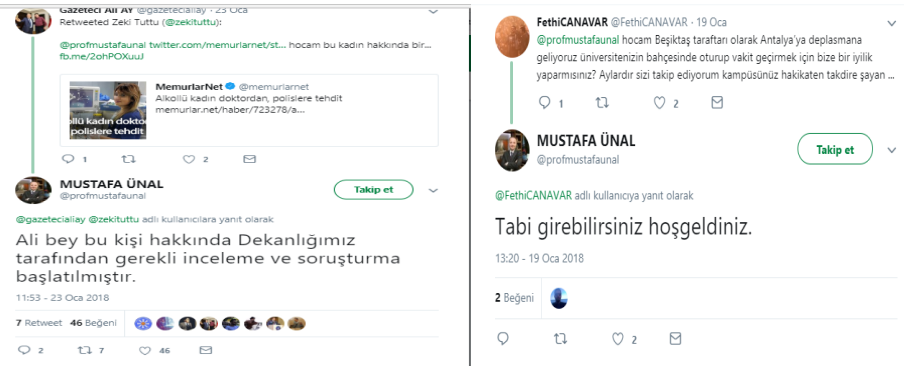

Resim 20: Etiketlenilen Paylaşımlara Cevap Verilen Twitter Paylaşımları

\subsubsection{Sakarya Üniversitesi Eski Rektörünün Twitter Kullanımına Yönelik Bulgular}

Sakarya Üniversitesi Eski Rektörü Prof. Dr. Muzaffer ELMAS, rektörlüğe atandığı tarihte farklı bir hesap kullanmasına karşın 2012 yılında, güncel olarak kullandığı hesabına geçiş yapmıştır. 2013 yılından itibaren gerek öğrencilerle iletişiminde gerekse eğitime yönelik paylaşımları için etkin şekilde Twitter hesabını kullanmaktadır. Twitter üzerinden@muzaffer_elmas kullanıcı adıyla öğrencilerle sosyal medya kanalıyla iletişim kuran ilk rektörlerden biri olarak ulusal basında haberler bulunmaktadır.

Tablo 6: Sakarya Üniversitesi Eski Rektörünün Twitter Kullanımına Yönelik Bulgular

\begin{tabular}{|c|c|c|c|c|c|}
\hline Tweet Türleri & Orijinal & Retweet & Alıntı & Soru cevap & \\
\hline & 2 & - & - & 33 & \\
\hline $\begin{array}{c}\text { Tweet } \\
\text { Içerikleri }\end{array}$ & Tanıtım & Duyuru & Soru Cevap & $\begin{array}{c}\text { Sosyal } \\
\text { Paylaşım }\end{array}$ & Diğer \\
\hline $\begin{array}{c}\text { Tweet } \\
\text { Etkileşimi }\end{array}$ & Cevaplanma & Beğeni & $\begin{array}{c}\text { Retweet } \\
\text { edilmesi }\end{array}$ & 5 & - \\
\hline & 28 & 27 & 11 & & \\
\hline $\begin{array}{c}\text { Tweet } \\
\text { Interaktifliği }\end{array}$ & Tek Yönlü & Çift Yönlü & & & \\
\hline & 2 & 33 & & & \\
\hline Kullanılan Dil & Formal & İnformal & & & \\
\hline & 14 & 21 & & & \\
\hline
\end{tabular}

Araştırmanın yapıldığı Ocak ayı içinde Prof. Dr. Muzaffer ELMAS 35 paylaşımda bulunmuştur.

Muzaffer Elmas Rektör olduğu süre boyunca gerek öğrencilerle olan diyalogları gerekse sosyal ve toplumsal mesajları ile Twitter etkili bir şekilde kullandığı için basında haber yapılan ilk rektör olmuştur. Muzaffer Elmas'ın rektör olduğu sürecin geneline göre paylaşımlarının araştırmanın yapıldığı süreçte daha az olması, bu sürecin görevinden 
ayrılmadan kısa bir süre öncesine rastlamasından dolayı şeklinde yorumlanmıştır.

Muzaffer Elmas'ın Twitter üzerinden öğrencilerle sağladığı dijital iletişimin dikkat çekici özelliklerinden birisi, öğrencilerin sorularına verdiği kısa, açık ve net cevaplardır. Bu konu birçok kez hem sosyal medyada hem de kendisi hakkında çıkan ulusal basın haberlerinde yer almıştır (resim 21).

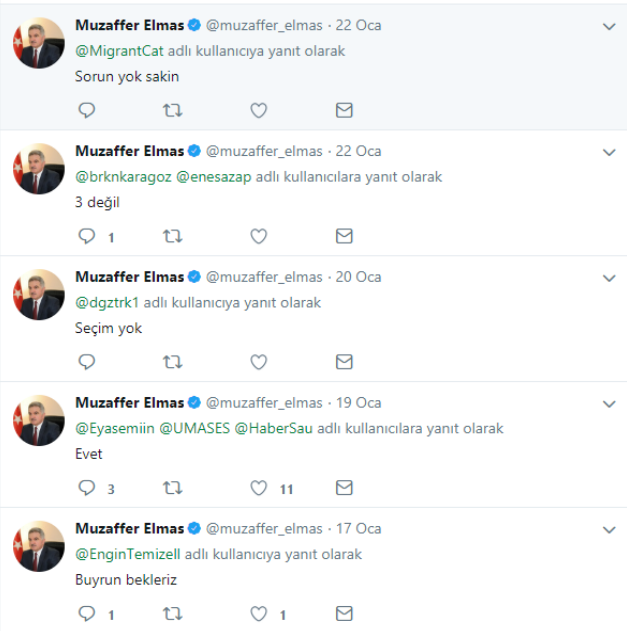

Resim 21: Cevap Tarzı Örneklerine İlişkin Twitter Paylaşımı

Paylaşımlar gerek tür gerekse içerik açısından incelendiğinde, kendisinin Twitter'dan kurduğu iletişim ortamında, 35 paylaşımının 33 tanesi soru cevap içeriklidir (resim 23). Soru cevap türündeki paylaşımlarındaki cevaplarda gerek farklı kurumlarla gerekse üniversitenin farklı bölümleri ile öğrenciler arasında bağ kurduğu gözlemlenmiştir.

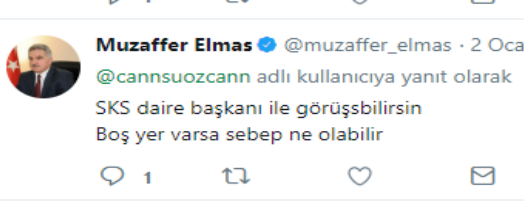

Resim 22: Öğrenci Sorunlarına İlişkin Twitter Paylaşımı

Soru ve cevapların yanı sıra toplumda ve dünyada olan önemli olaylar hakkında sosyal ve politik içerikli paylaşımları sık sık yaptığı tespit edilmiştir. Ülke ve dünya gündemindeki önemli gelişmelere ilişkin paylaşımları yüksek etkileşim oranlarına sahiptir (resim 23). Rektörün en fazla etkileşim alan paylaşımı 1252 beğeni alan toplumsal içerikli bir paylaşımıdır (resim 23). 
Muzaffer Elmas @muzaffer_elmas · 20 Oca 2018 Sınırlarımızın güvenliğini sağlamak için başlayan operasyonda Allah şanlı ordumuzun yardımcısı olsun.
7
$\uparrow 】 94$
1252

Resim 23: Sosyal ve Toplumsal İçerikli Twitter Paylaşımı

Muzaffer Elmas da katılımcı grubundaki diğer rektörler gibi üniversite dışından kişi ve kurumlarla da rektör kimliği altında sıkça çift tarafı etkileşime girmiştir (resim 24).

Muzaffer Elmas @ @muzaffer_elmas · 17 Oca 2018

@EnginTemizell adlı kullanıcıya yanıt olarak

Buyrun bekleriz

Resim 24: Üniversite Dışı Kişi ve Kurumlarla Kurulan İletişim Örneği için Twitter Paylaşımı

Muzaffer ELMAS'ın tüm paylaşımlarının beğeni, cevaplanma veya retweet etkileşimlerinden en az birini almış olması Twitter'da etkileşim sağlayabildiğini göstermektedir.

Öğrencilerle sık sık Twitter üzerinden iletişim kuran Muzaffer Elmas'ın sorulara verdiği cevaplarında sıklıkla mizahi bir söylem kullandığı görülmektedir (resim 25, 26).

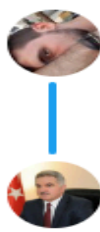

Emirhan Işık @isik_emirhan · 8 Oca 2018

@muzaffer_elmas hocam finaller geçti ama hala gece uyuyamıyorum. bahar finallerine șimdiden hazırım.

๑ 1

Muzaffer EImas

@muzaffer_elmas

Takip et

@isik_emirhan adlı kullanıcrya yanıt olarak

\section{Rüyadan uyanırsan iyi olur}

oo:32 - 9 Oca 2018

8 Beğeni

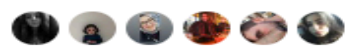

$\uparrow \beth$

O 8

Resim 25: Mizahi söylem örnekli Twitter Paylaşımı 
eren (M)masshypnozis - 26 Oca 2018

Turizmi bitirdim

Umarım Turist

Olurum

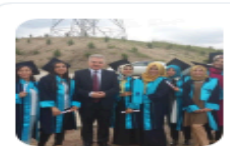

Muzaffer EImas @muzaffer elmas

Felsefeyi bitirdiler

Filozof oldular

Yolunuz bahtınız açık olsun

๑ $3 \quad \tau \neg 10 \quad 10 \quad \bigcirc \quad 103$

Muzaffer Elmas

@muzaffer_elmas

Takip et

@masshypnozis adlı kullanıcıya yanıt olarak

\section{Domates tarlası ile tarla domatesi farklı anlam taşır}

01:02 - 27 Oca 2018

5 Retweet 247 Beğeni

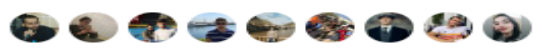

$\begin{array}{llll}1 & 5 & 247\end{array}$

Resim 26: Mizahi söylem örnekli Twitter Paylaşımı

Bununla birlikte rektörün tüm paylaşımlarının çift yönlü olması platformda çift taraflı etkileşimi sağlayabildiğinin göstergesidir.

Paylaşımlarında formal veya informal dil kullanmayı kendisine yöneltilen sorularda kullanılan dile göre seçmekte olduğu tespit edilmiştir (resim 27).

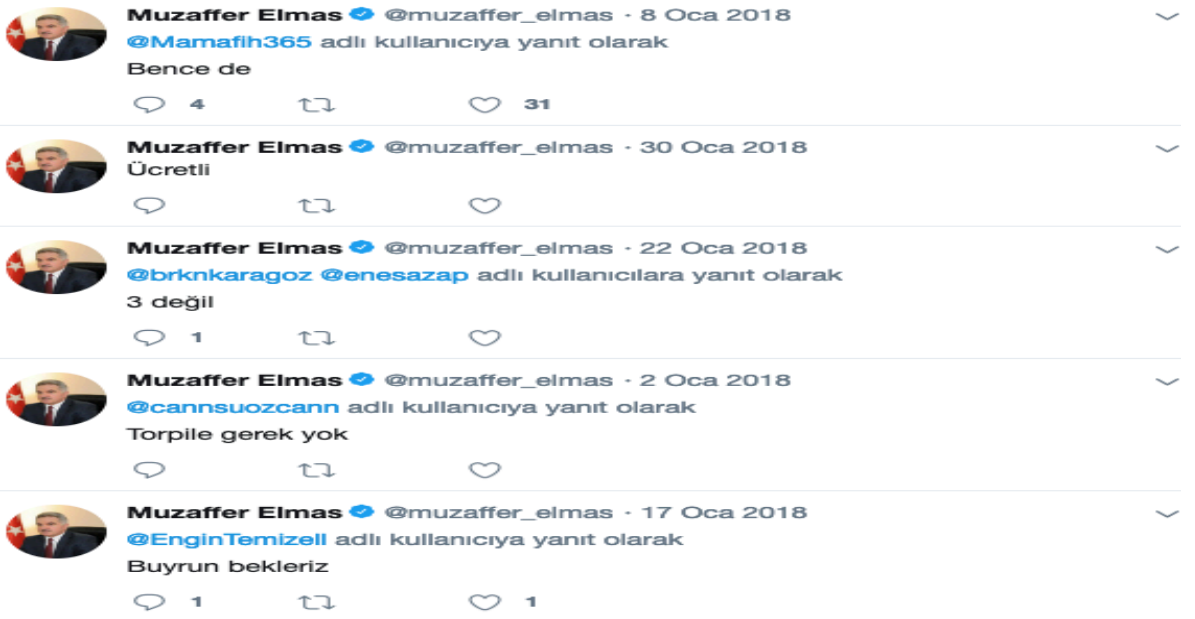

Resim 27: Dil Kullanım Örneği İçeren Twitter Paylaşımları

Araştırmada dikkat çeken bir başka nokta ise paylaşım özelliklerinden biri olarak kendisine yapılan eleştirilere de övgülere de aynı sakinlik ve tarafsızlıkla cevap vermesidir. Bu nokta ulusal basında çıkan haberlerde de yorumlanmışırı. 


\subsection{Yorum ve Tartıșma}

Yapılan çalışmada, sosyal ağ teorisi bağlamında yapılan incelemede ulaşılan bulgularla araştırma sorularına cevap aranmıştır.

Bu çerçevede, Twitter'da yaptıkları paylaşımlar incelenen Prof. Dr. Muhsin KAR (Niğde Ömer Halis Demir Üniversitesi), Prof. Dr. Mustafa ÜNAL (Akdeniz Üniversitesi) ve Prof. Dr. Muzaffer ELMAS'ın (Sakarya Üniversitesi) en çok soru-cevap türünde paylaşım yaptıkları görülmüştür. Bu durum sosyal medyanın iletişim mekanizması olarak kullanılmasıyla karşılıklı deneyim alışverişini sağlamanın bir yolunun bulunmuş olması şeklinde görülmektedir. Soru ve sorunların çözümü için farklı kurum ve kuruluşlara etiketleme yapılarak öğrencilerin bireysel paylaşımlarının gruplara ithaf edilmesi ile ortak bir kültür oluşturulmaya çalışıldığı görülmektedir. Yine bu noktada sosyal ağ teorisindeki temel unsurlardan biri olan kişilerin, grup ve organizasyonun bir parçasına dönüşmesine (Finin, vd., 2005: s.420) ilişkin yapılan bir çalışma olarak yorumlanabilir. Ayrıca tüm katılımcıların orijinal paylaşımlarında öğrencilerin bağlı bulundukları üniversiteye ilişkin ortak bir tavır geliştirmeye, eğitimlerine yönelik motivasyonlarını arttırmaya ilişkin paylaşımları sıklıkla tespit edilmiştir. Bu durum sosyal ağ teorisinde odaklanılan bilgi alışverişlerinde kişisel kanallar ve/veya medyanın etkilerinden yararlanma yolu ile davranışsal değişikliklerde ve/veya hareket kabiliyetinde sosyal ilişkilerin etkisini kullanma eğilimini destekler niteliktedir. Ayrıca yine teorinin temel mekanizmalardan biri olarak görülen sürekli iletişimde olmak ve birliktelik kurmaya olan mecburiyete katkı sağlaması şeklinde yorumlanabilir.

Bunun yanında sosyal medya fenomeni olarak anılan rektörlerin öncelikli olarak öğrenciler ve ikincil olarak diğer kişilerle veya kurumlarla çift taraflı etkileşim sağlamaları, sosyal ağ üzerinde yapılan paylaşımların çoğalarak kişilerin takipçi sayısının artmasına, paylaşımlarının retweet edilmesine ve dolayısı ile kişilerin ağ üzerinde tanınırığının artmasına neden olmaktadır. Çalışmanın alan yazınında da söz edildiği üzere, bu konudaki bulgular Rutter, Roper ve Lettice'in (2016: s.3099), bu alanda daha önce yapmış oldukları bir çalışmada öne sürülen üniversite yöneticilerinin sosyal medyayı etkin kullanımlarının hem kendilerini fenomenleştirdiği hem de yöneticisi oldukları üniversitenin tanınırlığını artırarak marka değerini yükselttiğini doğrulamaktadır.

Bu bağlamda, çalışmaya konu olan rektörlerin Twitter kullanımında en çok dikkat çeken nokta interaktifliktir. Kendilerinin etiketlendiği farklı tweetlere cevap veren rektörlerin aynı zamanda iletilmesini istedikleri mesajları yorumlu veya yorumsuz bir şekilde retweetlemeleri etkileşimi önemli ölçüde artırmıştır. Bununla birlikte, her üç rektöründe kendi oluşturdukları orjinal paylaşımların takipçileri tarafından sürekli olarak cevaplanıyor olması etkileşimin birincil nedeni olarak yorumlanmıştır.

Çalışmada incelenen tweet içeriklerine bakıldığında dil kullanımında farklılıklar ortaya çıkmıştır. Prof. Dr. Mustafa ÜNAL'a ait paylaşımların \%92'sinde formal bir dil tercih edilmişken, bu oran Prof. Dr. Muhsin KAR için \%39 formal ve \%61 informal olarak gerçekleşmiştir. Benzer şekilde Prof. Dr. Muzaffer ELMAS'a ait paylaşımların da \%60'ı informal dil içermektedir. Söz konusu bulgulardan hareketle kullanılan dilin yapısının (formal/informal) öğrenciler ve diğer kişi veya kurumlara ilişkin hesaplarla yapılan 
iletişim ve etkileşime bir etkisi olmadığı sonucuna ulaşılmıştır. Bu duruma ilişkilerdeki yapıları ve çıkarımları özel davranış ilkelerine göre açıklayan (Jones, 2009: s. 594) sosyal ağ teorisi bağlamında bakıldığında yapının kişiye özel olarak oluşması ve kabul edilmesi şeklinde yorumlanmaktadır.

\section{Sonuc}

Yapılan çalışmada ulusal ve yerel basının yanı sıra sosyal medyada en çok yer alan ve sosyal medya fenomeni olarak adlandırılan 3 farklı üniversite rektörünün sosyal medya platformlarından Twitter'daki paylaşımları ile ilgili mevcut durumu ortaya koymak amaçlanmıştır.

Üniversite üst yöneticilerinin sosyal medyayı bir iletişim ve etkileşim aracı olarak kullanmaları kendi tanınırlıklarına etki etmekle birlikte öğrencilerin istek ve şikayetlerine çözüm bulmada önemli bir fayda göstermektedir. Paylaşımların içerikleri incelendiğinde üniversite rektörü ile sosyal medya ortamında iletişim ve etkileşim içerisinde olan öğrencilerin motivasyonlarının olumlu yönde etkilendiğini ve kurumsal aidiyetlerinin arttığı, sosyal medyada takipçi sayısının sürekli olarak artmasını da sağladını söylemek mümkün olacaktır. Bununla birlikte, üniversite yöneticilerinin sosyal medya platformlarını etkin olarak kullanması üniversitenin tanınırlığını artırmakta ve marka değerini olumlu bir biçimde etkilemekte olduğu yorumu da yapılabilir.

Bununla birlikte, çalışmanın alan yazınında da tartışıldığı üzere Türkçede sosyal Medya Fenomeni olarak bilinen kavramların yabancı literatürde Micro-celebrity, Social Media Influencer, Micro- Influencer kavramları (Senfit, 2008; Hern ve Schoenhoff, 2016; Barhost, vd, 2019) üzerinden tartışıldığı görülmüştür.

Türkçedeki kullanımıyla Sosyal Medya Fenomeni olarak adlandırılan kişilerin kurumlar, marka ve hizmetlerin pazarlanmasında sosyal medyadaki takipçi sayılarını kullanarak maddi çıkar sağladıkları düşünüldüğünde, "Sosyal Medya Fenomeni" olarak kabul edilen bununla birlikte kamu yararı gözeten ve maddi bir beklenti olmadan yaptıkları paylaşımlarla yüksek etkişelim ve takipçi sayılarına ulaşan rektörlerin birer mikroşöhret (micro-celebrity) olarak tanımlanmaları daha doğru olmaktadır. Bu çerçevede, birer mikro-şöhret olarak ortaya çıkan "fenomen rektörler" in takipçi sayısı, güvenilirlik ve etki alanı açısından micro-influencer sınıflandırmasında yer alabileceği düşünülse de, rektörlerin marka ve hizmetlerle ilgili yorumlar yapmamaları, genel olarak sorun çözen makam olarak görülmeleri, eleştiri de bulunmaktan ziyade eleştiriye konu olan konumda bulunmaları bu tanımlamanın da yapılmasını olanaksız kılmaktadır.

Bu çerçevede, nitel bir yaklaşımla mevcut durumu ortaya koyan bu çalışmaya ek olarak ileriki çalışmalarda yükseköğretim kurumlarının ve yöneticilerinin kurumsal kimliklerinin bir parçası olarak kullandıkları sosyal medya araçlarının öğrencilerin motivasyonlarına, kurumsal aidiyet duygularına ve kurumun marka değerine katkısının nicel çalışmalarla incelenmesinin literatüre önemli katkılar sunacağı düşünülmektedir. 


\section{Kaynakça}

Agostino, D. ve Arnaboldi, M. (2016). Social media implementation in higher education institutions between mimicry and professionalism. XXVII RSA AilG 2016, Bergamo (Italy). https://core.ac.uk/download/pdf/83102295.pdf

Barhorst, J. B., McLean, G., Brooks, J., ve Wilson, A. (2019). Everyday micro-influencers and their impact on corporate brand reputation. 21st ICIG Symposium, 2019-06-04 - 2019-06-06, Durham Business School.

Barnes, N. G., ve Lescault, A. M. (2013). College presidents out-blog and out-tweet corporate CEO's. UMass Center for Marketing Research. http://www.umassd.edu/cmr/ socialmediaresearch/collegepresidentsoutblog/

Blumberg, H. ve Hare, P. A. (1999). Sociometry Applied to

Organizational Analysis: A Review. Action Methods, 52(1): s.65-97.

Breakenridge, D. (2008). PR 2.0: New Media, New Tools, New Audiences. New Jersey: FT Press.

Cantoni, L. ve Tardini, L. (2008). The Problem of Communication. P. C.

Doğru, Y.B. ve Doğru, S. (2015). Bir Halkla Iliş̧kiler Aracı Olarak Twitter: Rektörlerin Twitter Kullanım Analizi. 1. Ulusal Toplumsal ve Kurumsal Çatışmalar Çözümler Kongresi, Düzce Üniversitesi.18 Ocak 2018 tarihinde http://akademikpersonel.kocaeli.edu.tr/yusuf.dogru/bildiri/ yusuf.dogru13.10.2015_16.41.11bildiri.pdf adresinden edinilmiştir.

Eysenbach, G. ve Till, J.E. (2001). Ethical issues in qualitative research on internet communities. British Medical Journal, 323(2): s. 1103-1105.

Finin, T., Ding L., Zhou, L. J. ve Anupam, L. (2005). Social Networking on the semantic Web. The Learning Organization, 12(5): s.418-435.

Hearn, A. ve Schoenhoff, S. (2016). From celebrity to influencer: tracing the diffusion of celebrity value across the data stream. P. David Marshall ve S. Redmond, (Ed.) A companion to celebrity. Chichester: John Wiley \& Sons. s.194-212.

Hewson, C., Vogel, C. ve Laurent, D. (2015). Internet research methods. London: Sage. https:// doi. org/10.1515/9783110271355-016.

Hootsuite. (2018). 2018 Yılı Sosyal Medya Kullanım İstatistikleri. Erişim adresi https://blog. hootsuite.com/twitter-demographics/.

İnterpress. (2017). Rektörlerin Yerel ve Ulusal Başında Çıkan Haber Sayıları. Görüşme tarihi: 18.12.2017

Jones, B.S.(2009). Examining Information Behavior Through Social Networks AnInterdisciplinary Review. Journal of Documentation, 65(4): s.582-601.

Kenan, A.ve Shiri,A.(2009). Sociability and Social Interaction on Social Networking Websites. Library Review, 58(6): s.428-446.

Khamis, S., Ang, L. ve Welling, R. (2017). Self-branding, 'micro-celebrity' and the rise of Social Media Influencers. Celebrity Studies, 8(2): s.191-208, DOI: 10.1080/19392397.2016.1218292 
Kimchi, J., Polivka, B., ve Stevenson, J.S. (1991). Triangulation: Operational Definitions: Nursing Research. The Journal of Educational Technology, 40(6): s.364-386.

Kimmons, R., Veletsianos, G., ve Woodward, S. (2016). Innov. High Educ.. British Journal of Educational Technology, 42(3): s. 97. https://doi.org/10.1007/s10755-016-9375-6

Lei, L., Yuato, L., ve Luo, Y. (2019). Production and Dissemination of Corporate Information in Social Media: A review. Journal of Accounting Literature, 42(6): s.29-43.

Lietsala, K., Sirkkunen, E. (2008). Social Media: Introduction to the tools and processes of participatory economy. Tampere: Tampere University Press.

Manovich, L. (2001). The Language of New Media. Cambridge, Mass.: MIT Press.

Moreno, Jacob Levy. (1934). Who Shall Survive?. New York, USA: Beacon Press.

Page, R. (2012). The linguistics of self-branding and micro-celebrity in Twitter: The role of hashtags. Discourse\& Communication, 6(2): s.181-201, DOI: 10.1177/1750481312437441

Palmer, S. (2013). Characterisation of the use of Twitter by Australian universities. Journal of Higher Education Policy and Management, 35: s.333-344.

Roebuck, D. B., Siha, S. ve Bell, R. L. (2013). Faculty Usage of Social Media and Mobile Devices: Analysis of Advantages and Concerns. Interdisciplinary Journal of E-Learning and Learning Objects, 9(1): s.171-192.

Rutter, R., Roper, S. ve Lettice, F. (2016). Social Media Interaction, the University Brand and Recruitment Performance. Journal of Business Research, Elsevier, 69(8): s.3096-3104.

Ryan, J. A. (2010). History of The Internet and The Digital Future. London: Reaktion Books.

Safko, L., ve Brake, D. K. (2009). The Social Media Bible: Tactics, Tools, and Strategies for Business Success. New Jersey: John Wiley and Sons.

Scott, J. (1991). Social network analysis: A handbook. London, UK: Sage Publications.

Senfit, T.M. (2008). Camgirls: celebrity and community in the age of social networks. New York: Peter Lang.

Yıldırım, A. ve Şimşek, H. (2011). Sosyal Bilimlerde Nitel Araştırma Yöntemleri. Ankara: Seçkin Yayıncılık.

Yolcu, Ö. (2013). Twitter Usage of Universities in Turkey. The Turkish Online Journal of Educational Technology (TOJET), 12(2): s.360-371. 